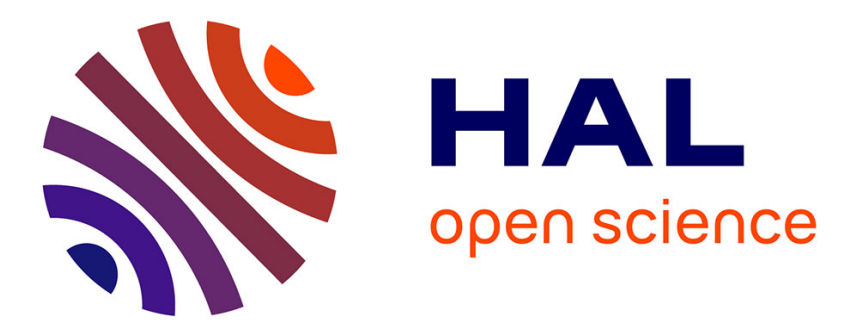

\title{
Effectiveness of policy measures to promote employee share ownership programs in banks \\ Tran Phan Huy Hieu
}

\section{To cite this version:}

Tran Phan Huy Hieu. Effectiveness of policy measures to promote employee share ownership programs in banks. 2020. hal-02534814

\section{HAL Id: hal-02534814 \\ https://hal-unilim.archives-ouvertes.fr/hal-02534814}

Preprint submitted on 7 Apr 2020

HAL is a multi-disciplinary open access archive for the deposit and dissemination of scientific research documents, whether they are published or not. The documents may come from teaching and research institutions in France or abroad, or from public or private research centers.
L'archive ouverte pluridisciplinaire $\mathbf{H A L}$, est destinée au dépôt et à la diffusion de documents scientifiques de niveau recherche, publiés ou non, émanant des établissements d'enseignement et de recherche français ou étrangers, des laboratoires publics ou privés. 


\title{
Effectiveness of policy measures to promote employee share ownership programs in banks
}

\author{
Phan Huy Hieu Tran ${ }^{1}$ \\ Université de Limoges, LAPE, 5 rue Félix Eboué, 87031 Limoges, France
}

April, 2020

\begin{abstract}
We investigate the effectiveness of the national supportive policy suggested by the European Commission to promote employee share ownership programs (ESOP) in European banks. We find that supportive measures are effective to promote ESOP in widely-held banks, independently of their degree of opacity and the level of shareholder protection. However, supportive measures are only effective to promote ESOP in closely-held banks if they are more transparent or located in countries with higher levels of shareholder protection. Our findings indicate that European countries not only need to implement supportive measures but also to enhance transparency and shareholder protection to promote ESOP. To identify the causal effect between the national supportive policy and ESOP adoption, we use the number of laborsupport-parties in parliament as the instrumental variable for the supportive measures.
\end{abstract}

JEL Classification: $621, G 28, G 38$

Keywords: Employee share ownership programs; Banks; Governance; Policy Evaluation.

\footnotetext{
${ }^{1}$ Email: phan-huy-hieu.tran@unilim.fr
} 


\section{Introduction}

Since 2012, the European Commission includes the promotion of employee share ownership programs (ESOP) in its action to reform European company law and corporate governance. The European Commission highlights the positive effects of employee shareholding on corporate governance by increasing information sharing, company transparency, and employee participation in decision making. The European Commission argues that, when employees hold an ownership stake, they demand full transparency on companies' accounts and decisions. Well-informed employees can make significant contributions to the effectiveness of company boards, especially their important function of monitoring and overseeing management (European Commission, 2014). Moreover, employeeshareholders can contribute to reduce firm risk-taking (Kolev et al., 2015) as they are riskaverse and have their job tied to the fate of their employer (e.g. Jensen \& Meckling, 1976; Amihud \& Lev, 1981). Based on these arguments, the European Commission recommends that EU member states should implement supportive policies to promote ESOP that should include two types of measures: legal measures to build a comprehensive legal framework, and fiscal measures to improve tax and financial incentives to implement an ESOP. In this paper, we investigate the effectiveness of these national supportive policies to promote ESOP in the European banking industry.

We focus on banks rather than on non-banking firms for several reasons. First and foremost, improving the corporate governance of banks to increase their transparency and reduce their risk-taking has become an important goal of financial regulatory authorities around the world after the global financial crisis. According to the arguments presented by the European Commission, the promotion of ESOP in the banking sector should help to achieve that goal. Second, banks are different from non-banking firms due to their specific regulation, capital structure (deposit funding with high leverage) and their inherent complexity and opacity (Morgan, 2002). The conflict of interest between different stakeholders in banks is more intense than that in non-banking firms. Focusing on banks therefore allows us to gain better insights into the impact of the agency conflicts between stakeholders on the decision of a bank to adopt an employee share ownership program. This can help policymakers to adjust their supportive policies to make them more effective.

The adoption of an ESOP, which turns employees into shareholders, changes the balance of power between insiders (managers in widely-held banks and majority shareholders in closely-held banks) and outsiders (minority shareholders). Insiders and outsiders of banks vote for or against an employee share ownership program by taking into account the potential 
impact of the program on their bargaining power. The decision of a bank to adopt an employee share ownership program can therefore be driven by its inner conflicts of interest between stakeholders.

In widely-held banks, the agency conflict is between managers and shareholders. The managers' major interest is to maximize job security. They therefore behave in a risk-averse manner against the interest of shareholders who want more risk to maximize profits (Amihud \& Lev, 1981). In such a situation, the presence of an employee share ownership program should be considered by shareholders as an effective mechanism to mitigate this agency conflict. However, Gamble (2000) argues that shareholders can also regard ESOP as a strategy of managers to protect their positions. When managers own shares via an ESOP, shareholders may find it difficult to organize a vote against management proposals or generate adequate momentum to replace top-level managers. In line with this argument, some studies find that the market reacts negatively when an ESOP is seen as a management entrenchment mechanism (Gordon \& Pound, 1990; Chang, 1990; Dhillon \& Ramírez, 1994).

In closely-held banks, the presence of large shareholders, who can act to replace ineffective managers if banks are not profitable, forces managers to become less risk-averse (Hill \& Snell, 1988). As a result, the conflict of interest switches from managers vs. shareholders to majority vs. minority shareholders, as large shareholders have incentives to maximize their benefits at the cost of minority shareholders (Shleifer \& Vishny, 1997). The incentives of majority shareholders to implement an ESOP are ambiguous. On the one hand, majority shareholders have incentives to use ESOP to align the interests of managers with those of shareholders. In line with this argument, Park \& Song (1995) find that the market reacts more favorably to an ESOP adoption in closely-held firms. On the other hand, majority shareholders are less likely to adopt an employee share ownership program as it will turn managers into minority shareholders. Managers will then defend the interest of minority shareholders, in particular by limiting any opportunist behavior of majority shareholders such as minority expropriation.

The existing literature examines the characteristics of firms that have adopted an ESOP and mainly focuses on US non-financial firms characterized by a widely-held ownership structure. To our knowledge, no paper examines the effectiveness of policies implemented by policy-makers to promote ESOP. Core and Guay (2001), examining the determinants of nonexecutive employee stock option holdings in US non-financial firms, find that the level of nonexecutives' option incentives is increasing in firms' growth opportunities, the relative importance of human capital as a factor of production, and firm size. Oyer and Schaefer (2005) 
further find that firms give stock options to all employees to increase employee efficiency and employee retention.

This paper aims to complete this literature by investigating whether the different measures implemented in the European countries to promote ESOP are effective to encourage banks to adopt such a program and if their effectiveness depend on bank ownership structure. In widely-held banks, supportive measures might be effective because they provide a legal framework that can reduce shareholders' concerns about managerial entrenchment as managers will receive extra remuneration and tax-saving with the adoption of an ESOP. Both managers and shareholders can therefore gain benefits from supportive measures for ESOP. On the contrary, supportive measures might be less effective to promote ESOP in closely-held banks if majority shareholders have an incentive to extract higher levels of private benefits at the cost of minority shareholders.

We further explore if the strength of the agency conflict, in both widely- and closelyheld banks, might have an impact on the effectiveness of the ESOP supportive measures. We use the degree of bank opacity and the level of shareholder protection as proxies to measure the strength of conflict of interest between insiders and outsiders. Lepetit et al. (2017) find that the degree of bank opacity and the level of shareholder protection influence the opportunistic behavior of insiders. They prove that banks with concentrated ownership pay lower dividends when they have high degrees of opacity, to extract higher levels of private benefits. They also find that higher shareholder protection helps to constrain this expropriation behavior of majority shareholders. Besides, La Porta et al. (2007) find that in countries with stronger levels of shareholder protection, minority shareholders use their legal powers to force companies to disgorge cash, thus precluding insiders to expropriate minority shareholders. We therefore examine the effectiveness of the supportive measures to promote ESOP in widely- and closelyheld banks under the effects of bank opacity and shareholder protection.

We use a unique hand-collected dataset on the ESOP adoption in annual reports of 103 listed banks in sixteen western European countries. We use a broad definition of employee ownership, covering the variety of programs in which employees (top managers with/without selected employees) are granted shares and share options. We consider that a reverse causality can exist between the national supportive policy and ESOP adoption due to the endogenous nature of the policy-making process. Supportive measures provide incentives for firms and employees to participate in ESOP while the rate of firms adopting ESOP may affect the decision of legislators to create or modify supportive measures. To tackle the challenge associated with endogeneity bias, we propose a novel instrumental variable defined as the number of political 
parties supporting labor rights in parliament. The rationale for this instrument is that ESOP, by offering employees an ownership stake in the company they are working for, should be largely supported by political parties who promote labor rights. Therefore, the number of laborsupport-parties in parliament should be mechanically correlated with the national supportive policy to promote ESOP, while it should not depend on or be influenced by the number of banks adopting ESOP.

Our results provide evidence that policies implemented by policy-makers in Europe are effective to promote ESOP in the banking sector. Further investigations show that the effectiveness of the ESOP supportive measures depend on the ownership structure of banks, as well as on their degree of opacity and the level of shareholder protection. More specifically, we find that supportive measures are effective to promote ESOP in widely-held banks independently of their degree of opacity and level of shareholder protection, while they are only effective to promote ESOP in closely-held banks when they have lower degrees of opacity or they are located in countries with stronger levels of shareholder protection.

This study makes several contributions to the literature. Firstly, it contributes to the literature on the determinants of ESOP in the banking industry. Secondly, it examines the effectiveness of the measures implemented at the national level in Europe to promote ESOP. To the best of our knowledge, no previous research has examined the effect of the national supportive policy on ESOP promotion. Thirdly, it investigates the complex interplay of agency problems faced by stakeholders on the effectiveness of ESOP supportive measures in both widely-held and closely-held banks. Our findings have relevant practical implications, as they suggest that the supportive measures may not in itself be enough to promote ESOP in closely-held banks. It is also fundamental to force closely-held banks to become more transparent and to implement stronger legal shareholder protection.

The remainder of the paper is organized as follows. Section 2 describes our sample, defines variables and presents the instrumental variable used to address the endogeneity problem. Section 3 presents the effects of the national supportive policy on ESOP adoption. Section 4 examines the effectiveness of supportive measures by taking into account the type and the strength of agency conflicts between insiders and outsiders. Section 5 contains robustness checks. Section 6 concludes the paper.

\section{Data, variables, and sample}

\subsection{Presentation of the sample}


We use the report published in 2014 by the European Commission on "the classification of European Union Member States based on regulatory density and support measures for employee financial participation" to collect data on the ESOP supportive measures (European Commission, 2014). As such a report was only published once in October 2014, we limit our main analysis to the year $2015^{2}$.

We manually collect data on ESOP in bank annual reports for the year 2015. We limit our analysis to listed commercial banks and bank holding companies in sixteen European developed countries (Austria, Belgium, Denmark, Finland, France, Germany, Greece, Ireland, Italy, Netherlands, Norway, Portugal, Spain, Sweden, Switzerland, and the United Kingdom) where the code of corporate governance for the listed firms requires firms to disclose information on ESOP in their annual reports.

According to the European Commission, employee financial participation schemes (EFP) has three main forms: profit sharing, employee share ownership, and employee share options. Profit-sharing may take the form of immediate cash bonuses, cash transfers to employee savings funds, or free equity shares. Employee share ownership may take the form of share purchase plans, free shares financed out of profits, or shares transferred to a collective trust financed by a loan secured against future profits. For employee share options, employees are granted a right to acquire shares at some future point at a price set when the right is granted. Employees are only granted ownership through employee ownership schemes, including employee share ownership and employee share options. Profit-sharing schemes grant employees extra remuneration depending on the performance of the company but they do not grant employees an ownership stake. The European Commission therefore separately quantifies supportive measures of each country for employee ownership schemes and profit-sharing. In our analysis, we focus on the supportive measures aiming only to promote employee ownership schemes, and exclude profit sharing. We then create a dummy dependent variable to indicate whether a bank has an employee share ownership program in 2015, taking the value of one if bank employees (top managers with/without selected employees) are granted shares or share options through employee share ownership or employee share options schemes.

We extract financial data and ownership structure from the Bankscope database. The market data used to measure the degree of bank opacity are extracted from Bloomberg. After dropping observations with missing values for the financial variables, our final sample consists

\footnotetext{
${ }^{2}$ We use the data colleted for the year 2014 to test the robustness of our results to the year-to-year variation (see Section 5).
} 
of 103 European listed banks (over 111 listed banks), including 66 commercial banks and 37 bank-holding companies see Table A.1 in Appendix A for a breakdown by country.

\subsection{The national supportive measures}

We construct the variable Country index to measure the national supportive policy of a country to promote ESOP. The Country index comprises two components: Legal index and Fiscal index. These indices are based on scores used by the European Commission to quantify the degree of the legal framework and financial incentives of each European country to promote ESOP (The European Commission, 2014). ${ }^{3}$ According to the European Commission, the scores of the legal framework and fiscal incentives are quantified as follows.

The legal score is an indicator that evaluates the presence or absence of regulations relating to the implementation of ESOP. It varies from 0 to 3. It equals to 0 if a country has no systematic regulation of ESOP and its general regulations neither promote nor inhibit the development of ESOP. It equals 1 if a country has an isolated regulation on one aspect of ESOP (usually company law). It equals 2 if a country has a systematic regulation of more than one aspect of ESOP (usually tax and company law). It equals 3 if a country has a systematic regulation of more than one aspect of ESOP and one or more additional aspects (connection to securities law, labor law, social legislation, etc.).

The fiscal score is an indicator that measures tax and financial incentives for companies and employees to adopt an ESOP. It varies from 0 to 4 . It equals 0 if a country has no special tax incentives and its general system of taxation neither promotes nor inhibits the development of ESOP. It equals 1 if a country has some tax incentives for companies and employees participating in ESOP, but their impact is not clear. It equals 2 if a country has some tax incentives and the difference between the effective tax rate on employee salary and firm income through ESOP is significant. It equals 3 if a country has tax incentives that are applicable to most enterprises and the criteria for these tax incentives are clearly defined and not restrictive. It equals 4 if a country has effective tax incentives and, additionally, other instruments of fiscal support such as government-backed loans for ESOP.

\footnotetext{
${ }^{3}$ The scores of the legal framework and fiscal incentives are presented in the Table "the classification of European Union Member States based on regulatory density and support measures for employee financial participation" in the report "The Promotion of Employee Ownership and Participation" of the European Commission published in October 2014, see https://op.europa.eu/en/publication-detail/-/publication/c184fcde-ecd7-11e5-8a81-01aa75ed71a1/languageen/format-PDF/source-search).
} 
We use the scores of the legal framework and fiscal incentives as the Legal index and Fiscal index, respectively. We combine these two indices into the Country index, which measures the national supportive policy of each country to promote ESOP. The Country index therefore varies from 0 to 7 . The higher the Country index, the better the support from the government for the development of ESOP

Table A.1 in Appendix A provides descriptive statistics of the national supportive measures. We observe that there is a strong heterogeneity among the European countries we consider, with the legal and fiscal indices ranging from zero to their maximal value.

\subsection{Widely-held vs. closely-held banks}

We follow the existing literature (La Porta et al., 1998; Claessens et al., 2002; Faccio \& Lang, 2002) by using the controlling threshold of $20 \%$ of outstanding shares to distinguish between widely-held and closely-held banks. We define a bank as a closely-held bank if it has at least one controlling shareholder who owns at least $20 \%$ outstanding shares. Banks without controlling shareholders are defined as widely-held banks. We also test the robustness of our results by using the control threshold of $10 \%$ instead of $20 \%$ (see Section 5).

Table A.2 in Appendix A displays descriptive statistics of banks having ESOP among widely- and closely-held banks. We observe that around 53\% and 59\% of widely-held and closely-held banks have adopted an ESOP, respectively.

We compute the dummy variable D_Controlling, which equals 1 if banks are closelyheld and equals 0 if banks are widely-held banks.

\subsection{Proxies to measure of the strength of agency conflicts}

The evidence from existing studies so far shows that opacity and shareholder protection influence the opportunistic behavior of insiders (majority shareholders and managers) in expropriating minority shareholders (e.g. Lepetit et al., 2017; Brockman \& Unlu, 2011; Eije \& Megginson, 2008; Li \& Zhao, 2008).

We follow Lepetit et al. (2017) to construct an opacity index (Opacity). We measure four components of opacity: (EF) measures the disconnection between insiders' and outsiders' information about firms' financial condition by computing the analyst forecast error; (EM) measures accounting opacity and is computed by the degree of earnings management of banks; (MF) is the negative of the ratio of short term and long term market funding to total assets measuring banks' exposure to the market; (Loan) loans over total assets. Then, associating each component with the value of 1 to 10 corresponding to the decile of 1 to 10 . After that, summing 
up four proxies, then divide it by four to scale the composite index. This index ranges from 1 to 10 . The most transparent bank has a value of 1 and the most opaque bank has a value of 10 .

We use the measurement of La Porta et al. (1998) and revised by Djankov et al. (2008) to measure the level of shareholder protection in each country. The index RADI measures the level of shareholder rights for each country, i.e. the legal protection of shareholders against expropriation by managers through several measures. This index varies from 0 (for weak protection countries) to 6 (for strong protection countries). For our sample, the index ranges from 2 (Greece and Italy) to 5 (UK).

\subsection{Endogeneity and instrumental variables}

In this section, we identify endogeneity problems and propose the instrumental variable approach to address this issue.

First, the causal effects between ESOP and bank financial characteristics can produce biased results. Firm performance and financial outcome ratios are factors that potentially influence the decision of shareholders on whether or not to adopt an employee share ownership program. However, existing studies show that ESOP have a significant impact on firm performance (e.g., Dhillon \& Ramírez, 1994; Jones \& Kato, 1995; Ding \& Sun, 2001; Cin \& Smith, 2002; Lampel et al., 2012). ESOP also have a negative curvilinear relationship with the cost of debt and the weighted average cost of capital (Aubert et al., 2017). Managerial ownership has a positive impact on firm value (Drakos \& Bekiris, 2010). Moreover, ESOP can also lead to an increase in firm equity and total assets if the firm decides to take loans to finance its employee share ownership programs. Throughout our analysis, we therefore use one-year lagged values of the control variables for bank financial characteristics to avoid any potential reverse causal effects between bank financial characteristics and ESOP adoption. It is clear that if a bank decides to adopt an employee share ownership program in a given year, this program cannot reversely affect the banks' financial outcomes one year ago.

Second, and most importantly, the reverse causality between the national supportive policy and ESOP adoption could afflict our analysis due to the endogenous nature of the policymaking process. The European Commission recommends that the national supportive policy promotes ESOP adoption. Reversely, the number of firms adopting ESOP may also affect the decision of legislators to create, modify or abolish supportive measures. If more and more firms adopt ESOP, it increases the need to have a comprehensive legal framework for different implementations of ESOP. Moreover, it is worth noting that the national supportive policy provides tax-deduction and other financial incentives for firms and employees participating in 
ESOP, a higher rate of ESOP acceptance in the business community, therefore, strengthens motivation of interest groups (such as business associations and labor unions) to pursue legal lobbying activities to create more supportive measures. This argument is consistent with the existing political studies such as Nelson and Yackee (2012) and Yackee (2012) which find that, in the policy-making process, interest groups commonly join together to promote or thwart government policy change.

Therefore, we use a novel instrumental variable approach to tackle the challenge of capturing plausibly exogenous variation in the national supportive policy. We instrument the national supportive policy by the total number of political parties in parliament who support labor rights, including socialist (except the green party) ${ }^{4}$, communist and labor parties.

The logic of our approach relies on the argument that political parties in parliament create and support laws that are consistent with their political ideology. Political parties who support labor rights can regard ESOP as a positive method to grant employees an ownership stake of the company where they are working for. Therefore, the greater the number of laborsupport-parties in parliament, the more the national supportive measures for ESOP could be approved.

The conceptual premise for the relevance of our IV is that the number of labor-supportparties in parliament is mechanically correlated with the national supportive measures for ESOP. In contrast, the number of labor-support-parties in parliament does not depend on or is influenced by bank characteristics.

\section{The national supportive policy and ESOP adoption}

In this section, we discuss our evidence about the effect of the national supportive policy on ESOP adoption. We then discuss the effect of each type of supportive measures on promoting ESOP.

\subsection{Does the national supportive policy promote employee share ownership programs?}

We conduct a cross-sectional regression analysis to examine the effect of the national supportive policy (Country index) on ESOP. We use two models for this test. First, we use the probit model. Second, we run two-stage least squares (2SLS) regressions in the ivprobit model

\footnotetext{
4 Thirty-four Green parties from all over Europe have joined to form The European Green Party since 2004. The party commits to basic tenets of Green politics, such as environmental responsibility, individual freedom, inclusive democracy, diversity, social justice, gender equality, global sustainable development and non-violence. However, labor rights are not mentioned in the party's motto.
} 
by using the number of labor-support-parties in parliament as an instrumental variable for the national supportive policy.

The equation for the probit model is as follows:

$$
\text { Pro }\left\{E_{S O P}=1\right\}=\Phi\left(\beta_{0}+\beta_{1} * \text { Country Index }_{i}+\sum_{m} \theta_{m} \text { Control }_{i}\right)
$$

The equations of the first and second stage of the two-stage least squares (2SLS) regressions in the ivprobit model are as follows:

$$
\begin{gathered}
\text { Country Index } i=\beta_{0}+\beta_{1} * \text { LaborSupportParties }_{i}+\sum_{m} \theta_{m} \text { Control }_{i}+\varepsilon_{i} \\
\text { Pro }\left\{E_{E S O P_{i}}=1\right\}=\Phi\left(\beta_{0}+\beta_{1} * \text { Instrumented_Country Index }_{i}+\sum_{m} \theta_{m} \text { Control }_{i}\right)
\end{gathered}
$$

The Instrumented Country index in Equation (2.2) is the predicted values of the Country index in the equation (2.1).

We use a set of control variables including bank characteristics as well as institutional characteristics which can potentially affect the decision of banks to adopt an employee share ownership program. We follow Core and Guay (2001) and Oyer and Schaefer (2005) to expect that bank size, bank growth opportunities and bank risk influence ESOP adoption. We use the natural logarithm of total assets (Size) and the growth of total assets (Growth_TA) to measure bank size and bank growth opportunities, respectively. We measure bank risk by using Zscore following Laeven and Levine (2009), Lepetit and Strobel (2013), and Lepetit and Strobel (2015). We also measure bank profitability by the return on equity ratio (ROE); bank capital leverage by the equity to total assets ratio (Equity_TA); and bank funding structure by the ratio of total deposits to total assets (Deposit_TA). We expect that bank financial characteristics affect the decision of shareholders and managers to participate in ESOP. However, the magnitude and the sign of the relation between bank financial characteristics and ESOP adoption is not clear. On the one hand, larger banks with higher growth opportunities and lower risk may have more financial resources to implement ESOP. These banks also are more likely to use ESOP to increase employee efficiency and employee retention. This argument is consistent with the study of Oyer and Schaefer (2005) in which they find that firms give stock options to all employees to increase employee efficiency and employee retention. On the other hand, smaller banks with lower growth opportunities and higher risk may also use ESOP as a mechanism to increase bank equity without diluting outstanding shares, consistent with the study of Core and Guay (2001) finding that firms use greater stock option compensation when facing capital requirements and financing constraints. We also include the dummy variable D_controlling that takes the value 1 for closely-held banks and 0 for widely-held banks. As explained above, we expect the ownership structure to influence banks' decision to adopt an 
ESOP. We also use an index (individualism) based on the work of Hofstede (2001) to measure the distinction between collective (group-based) and individual-based decision making of a country. According to Caramelli and Briole (2007), some different adaptations in the employee share ownership program's design and communication are recommended to improve its attitudinal effects in collectivistic societies and individualistic societies. Thus, the effectiveness of the national supportive policy to promote ESOP can be influenced by country culture.

Table 1 shows definitions, data sources and summary statistics for variables. Extreme bank-year observations are winsorized (1\% lowest and highest values). We analyze the correlation coefficients between our control variables and find that all variance inflation factors (VIF) are smaller than 5 (see Appendix B). ${ }^{5}$

\section{[Insert Table 1]}

Table 2 presents the results of our baseline test. The dependent variable is the dummy variable $D \_E S O P$. All control variables for bank financial characteristics are lagged values. Columns 1 reports regression estimates for the probit model without using the instrument variable. Columns 2 and 3 report the first and the second-stage results for our IV estimations. The national supportive policy (Country index) is instrumented with the number of laborsupport-parties presented in parliament. Column 4 reports the marginal effects of the ivprobit model.

The probit estimates in Column 1 show that the national supportive policy has a significant (at the 1\% level) and positive impact on ESOP adoption. This result, however, can be biased because of the reverse causal effects between the national supportive policy and ESOP adoption.

As previously explained, we propose a novel approach to tackle the reverse causal effect problem. Columns 2 and 3 in Table 2 report the first and the second-stage results for our IV estimation, respectively. The first-stage estimates show that there is a significant (at the $1 \%$ level) and positive relationship between the number of political parties in parliament who support labor rights and the national supportive policy. Both the Anderson-Rubin test and the Wald test have p-values smaller than 0.05 , indicating that our IV passes the "weak instrument test". This confirms that our IV is empirically relevant.

\footnotetext{
5 Appendix B shows that the correlation coefficients among control variables are low except the coefficients between: Size - EQ_TA; Size - Deposit_TA; Size - Opacity; and ZScore - ROE. However, Collinearity Diagnostics indicate that all variance inflation factors (VIF) are smaller than 5. Thus, there is no serious collinearity problem among our control variables. Moreover, in section 5, we use orthogonalized variables to re-conduct our analysis. Our results are unchanged. We therefore use original values of control variables in our main analysis.
} 
The second-stage estimates of the relation between the national supportive policy and ESOP adoption are quantitatively in line with the original probit model. The results in Column 3 shows that the national supportive policy instrumented with the number of labor-supportparties has a statistically significant and positive effect on ESOP adoption. Column 4 shows the economic effects of the national supportive policy on ESOP adoption. It implies that a one-unit increase in the country support index is associated with an increase in the probability of a bank adopting ESOP of 0.111 .

Overall, the results in Table 2 show that a higher level of the national supportive policy is significantly associated with higher ESOP adoption. It provides evidence that national supportive measures are effective to influence the decision of banks to adopt an ESOP and supports therefore the recommendation of the European Commission that the state members should create supportive measures to promote ESOP.

[Insert Table 2]

\subsection{Which type of supportive measures matter?}

We find that the national supportive policy is significantly correlated with ESOP adoption. However, this result can reflect only the dominant effect of one component of the national supportive policy. In the next set of tests, we breakdown the country support index by its components to examine the impact of each component on ESOP adoption. Because we focus on the impact of each index, we repeat the baseline test for each component (Legal index and Fiscal index) one by one. Moreover, we also test the validity of our IV for each component of the national supportive policy.

We alternately replace Country index by Legal index and Fiscal index in Equations (2.1) and (2.2). Table 3 reports regression estimates of the ivprobit models. Columns 1 and 2 report 1st and 2nd stage ivprobit regression estimates obtained when Legal index is instrumented with the number of labor-support-parties. Columns 3 and 4 report 1st and 2nd stage ivprobit regressions obtained when Fiscal index is instrumented with the number of labor-supportparties.

The results show that each component of the national supportive policy affects significantly and positively ESOP adoption. This result implies that the effect of the national supportive policy does not reflect only one dominant effect among its components but it is a combined effect of all different supportive measures. 
Consistent with the logic of our IV, the Anderson-Rubin test and the Wald test have pvalues smaller than 0.05 in all cases, this confirms that our IV passes the "weak instrument test".

[Insert Table 3]

\section{The role of the ownership structure, the degree of opacity and the level of shareholder protection}

\subsection{Agency conflicts and effectiveness of ESOP measures}

Our evidence to this point shows that the national supportive policy and each of its components have a significant and positive impact on ESOP adoption. However, as the agency conflict of interest between managers vs. shareholders in widely-held banks is different with the principal - principal conflict of interest between majority vs. minority shareholders in closely-held banks, we examine whether the effectiveness of the national supportive policy and each of its component is driven by bank ownership structure.

In widely-held banks where the conflict of interest is between managers vs. shareholders (Hill and Snell, 1988), shareholders have the incentive to adopt ESOP to make managers less risk-averse. However, the risk of managerial entrenchment might reduce their motivation to adopt ESOP (Gamble, 2000). In closely-held banks where the conflict of interest is between majority vs. minority shareholders (Shleifer and Vishny, 1997), minority shareholders will vote for an ESOP proposal while majority shareholders are more likely to be "anti-ESOP". We conjecture that supportive measures are more effective to promote ESOP in widely-held banks as they provide a legal framework that can reduce shareholders' concerns about managerial entrenchment. Majority shareholders in closely-held banks might vote against the adoption of an ESOP as it will turn managers into minority shareholders.

We analyze how the ownership structure of banks has an impact on the effectiveness of ESOP measures by expanding Equation (2.2) with an interaction term between the Instrumented Country index and D_Controlling as follows:

$$
\begin{array}{rl}
\text { Pro }\left\{\operatorname{ESOP}_{i}=1\right\}=\Phi\left(\beta_{0}+\right. & \beta_{1} * I_{-} \text {Country Index }_{i}+\beta_{2} * \mathrm{IV}_{-} \text {Country Index } \\
i & * \mathrm{D}_{-} \text {Controlling }_{j} \\
& \left.+\sum_{m} \theta_{m} \text { Control }_{i}\right)
\end{array}
$$

We alternately replace the Instrumented Country index by the Instrumented Legal index and the Instrumented Fiscal index in Equation (3).

Table 4 reports regression estimates of the 2 nd stage of the ivprobit models where the dependent variable is D_ESOP. Columns 1, 2, 3 report the results when Country index, Legal index, and Fiscal index is instrumented with the number of labor-support-parties, respectively. 
The results show that the coefficients of Instrumented Country index, Instrumented Legal index, and Instrumented Fiscal index are significant (at the 1\% level) and positive. These results indicate that, in widely-held banks, the national supportive policy and each of its components have a significant and positive impact on ESOP adoption, consistent with our conjecture. On the contrary, the results of the Wald tests show that the coefficients of the indices are insignificant in the case of closely-held banks. It indicates that all supportive measures are ineffective to promote ESOP in closely-held banks.

Overall, we find that the supportive measures are only effective to promote ESOP in widely-held banks but they are ineffective for closely-held banks.

[Insert Table 4]

\subsection{Strength of the agency conflicts}

We next explore whether the strength of the conflict of interest between insiders and outsiders, measured either by the degree of opacity or the level of shareholder protection, has an impact on the effectiveness of the ESOP supportive measures in both widely- and closelyheld banks. Again, we conjecture that supportive measures are more effective to promote ESOP in widely-held banks, independently of the strength of the agency conflict. In closely-held banks, existing studies show evidence that opacity and shareholder protection affect significantly the opportunistic behavior of majority shareholders (Lepetit et al., 2017; La Porta et al., 2007). We therefore expect the degree of bank opacity and the level of shareholder protection to have an impact on the decision of majority shareholders to adopt an ESOP.

We create the dummy variable $D \_$Opacity, which takes the value one if the bank has a degree of opacity higher than the median of the sample; it takes the value zero otherwise. We also create the dummy variable $D \_R A D I$ which takes the value one if the level of shareholder protection of a country is lower than the median of the sample; it takes the value zero otherwise. We augment Equation (3) with triple-interaction terms between the national supportive policy (Instrumented Country Support Index), the ownership structure (D_Controlling); and either bank opacity (D_Opacity) or shareholder protection $\left(D \_R A D I\right)$ as follows:

Pro $\left\{E S O P_{i}=1\right\}=\Phi\left(\mathrm{b}_{0}+\mathrm{b}_{1} * \mathrm{IV}_{-}\right.$Country index $\mathrm{i}_{\mathrm{i}}+\mathrm{b}_{2} * \mathrm{IV}_{-}$Country index $\mathrm{i}_{\mathrm{i}} * \mathrm{D}_{-}$Controlling $\mathrm{j}_{\mathrm{j}}+\mathrm{b}_{3} *$ IV_Country index $x_{i} * D_{-}$High_conflict $+\mathrm{b}_{4} * \mathrm{IV}_{-}$Country index ${ }_{\mathrm{i}} * \mathrm{D}_{-}$Controlling ${ }_{\mathrm{j}} * \mathrm{D}_{-}$High_conflict +

$$
\left.+\sum_{m} \theta_{m} \text { Control }_{i}\right)
$$

Where D_High_conflict represents the strength of the agency conflicts, measured either D_Opacity or D_RADI. We alternately replace the Instrumented Country Index with the 
Instrumented Legal index and the Instrumented Fiscal index to examine the effectiveness of each type of supportive measures.

We first examine the effect of bank opacity on the effectiveness of supportive measures in both widely-held banks and closely-held banks. Table 5 reports regression estimates of the 2nd stage of the ivprobit models. Column 1, 2, 3 report the results when Country index, Legal index, and Fiscal index is instrumented with the number of labor-support-parties, respectively. The results of the Wald tests in Table 6 show that the national supportive measure and each of its components are effective to promote ESOP adoption in widely-held banks, independently of their degree of opacity. This result is consistent with our conjecture that in widely-held banks, both parties of the conflict of interest (managers vs. shareholders) gain benefits from the ESOP supportive measures. The results in Table 6 further show that, although supportive measures are not effective to promote ESOP in closely-held banks having higher degrees of opacity, they become effective when these banks have lower degrees of opacity. As majority shareholders can take advantage of higher degrees of opacity to extract private benefits, they have no incentive to approve an employee share ownership program which can reduce their advantages. However, if banks are transparent, it will be difficult for majority shareholders to hide any opportunistic behavior. In such a situation, the benefits from the ESOP supportive measures can motivate majority shareholders to adopt an ESOP.

\section{[Insert Tables 5 \& 6]}

We next examine whether the effectiveness of supportive measures depend on the level of shareholder protection to promote ESOP adoption in both widely-held banks and closelyheld banks. Lower levels of shareholder protection indicate that the strength of the agency conflict between insiders and outsiders is higher. Table 7 reports regression estimates of the 2nd stage of the ivprobit models where the dependent variable is D_ESOP. Columns 1, 2 and 3 report the results when Country index, Legal index, and Fiscal index is instrumented with the number of labor-support-parties, respectively. Table 8 reports the Wald tests from Table 7. Consistent with the results drawn from the previous sections, we find that the national supportive policy and each of its components are effective to promote ESOP in widely-held banks independently of the level of shareholder protection. This result, once again, confirms that both parties of the agency conflict in widely-held banks gain benefits from supportive measures and thus, they have the incentive to adopt ESOP.

The results also show that supportive measures are only effective to promote ESOP in closely-held banks if they are located in countries with higher levels of shareholder protection. 
This result is consistent with the study of La Porta et al. (2007) which states that, in countries with stronger levels of shareholder protection, minority shareholders use their legal powers to force companies to disgorge cash, thus precluding insiders to expropriate minority shareholders. Our results indicate that in countries with higher levels of shareholder protection, minority shareholders have the legal power to force majority shareholders to adopt ESOP.

[Insert Tables $7 \&$ 8]

Overall, the evidence in this section shows that supportive measures are effective to promote ESOP adoption in widely-held banks independently of the degree of bank opacity and the level of shareholder protection. However, they are only effective to promote ESOP adoption in closely-held banks when they are more transparent and/or located in countries with higher levels of shareholder protection.

\section{Robustness tests}

In this section, we conduct several tests to assess the robustness of our results.

\subsection{The year-to-year variation.}

We use "the classification of European Union Member States based on regulatory density and support measures for employee financial participation" of the European Commission (European Commission, 2014) which is only published once in October 2014 to measure the national supprotive policy. We therefore limit our main analysis to the year 2015 . To test the robustness of our results for the year-to-year variation, we collect data on ESOP in bank annual reports for the year 2014 to re-conduct our analysis.

Table $\mathrm{C} 1 ; \mathrm{C} 2$; $\mathrm{C} 3$; and $\mathrm{C} 4$ in Appendix $\mathrm{C}$ report the regression estimates of the ivprobit models. Our results are unchanged. We find that all supportive measures are effective to promote ESOP in widely-held banks independently of bank opacity and shareholder protection. However, they are only effective to promote ESOP in closely-held banks if the banks are transparent and/or located in countries with higher levels of shareholder protection. The IV also passes the IV tests.

\subsection{Alternative ownership threshold of controlling shareholder}

To test whether our results are affected by the ownership threshold used to distinguish between widely-held banks and closely-held banks, we use an alternative ownership threshold at $10 \%$ of outstanding shares to re-conduct our analysis following the existing literature (La 
Porta et al., 1999, 2002; Lepetit et al., 2015). The results displayed in Appendix D show again that our main results are unchanged.

\subsection{Orthognalizing variables}

Appendix B shows the correlation matrix of the independent variables. The correlation coefficients are low except the coefficients between Size - EQ_TA, Size - Deposit_TA, Size Opacity, and ZScore - ROE. To test whether the correlations between these variables affect our results, we orthogonalize EQ_TA, Deposit_TA, and Opacity with Size. We also orthogonalize $R O E$ with ZScore. We then re-conduct our analysis by using orthogonalized variables.

The results in Appendix E show that these specifications lead to results quantitatively similar to our previous inferences. We still find that all supportive measures are effective to promote ESOP in widely-held banks independently of bank opacity and shareholder protection. However, they are only effective to promote ESOP in closely-held banks if the banks are transparent and/or located in countries with higher levels of shareholder protection. The IV passes the IV tests.

Overall, the evidence from the tests in this section demonstrates that our results are robust to variations in model specifications, alternative ownership threshold to distinguish between widely-held and closely-held banks, and the year-to-year variation.

\section{Conclusion}

Since 2012, the European Commission includes the promotion of ESOP in its action to reform European company law and corporate governance. According to the Commission, through ESOP, employees are encouraged to actively contribute to good corporate governance by increasing company transparency and reducing risk (European Commission, 2014). Because enhancing banking corporate governance is an important goal of financial regulators all over the world after the global financial crisis, the promotion of ESOP in banks is therefore particularly important. We investigate how the effectiveness of the national supportive measures suggested by the European Commission to promote ESOP is influenced by bank ownership structure, bank opacity and the level of shareholder protection.

We find that the national supportive policy plays an important role in promoting ESOP adoption in banks. Our results show that all supportive measures (legal and fiscal measures) have a significant and positive impact on the probability of a bank adopting ESOP. We find that supportive measures are effective to promote ESOP adoption in widely-held banks independently of their degree of opacity and the level of shareholder protection. On the 
contrary, supportive measures are only effective to promote ESOP in closely-held banks if they are more transparent or located in countries with higher levels of shareholder protection.

Our findings have an important implication for policymakers to promote ESOP in the European banking industry. As highly concentrated ownership are prevalent in banking firms in continental Europe (La Porta et al., 1998), our results indicate that the supportive measures implemented at the national level might be ineffective to promote ESOP if bank transparency is not improved and if the level of shareholder protection is not reinforced. 


\section{References}

Amihud, Y., Lev, B.,1981. Risk Reduction as a Managerial Motive for Conglomerate Mergers. The Bell Journal of Economics. 12(2) 605-617.

Aubert, N., Kern, A., \& Hollandts, X. (2017). Employee stock ownership and the cost of capital. Research in International Business and Finance, 41, 67-78.

Becht, M., Bolton, P., Roell, A., 2002. Why bank governance is different. Oxford Review of Economic Policy. 27(3), 437 - 463.

Brockman, P., Unlu, E., 2011. Earned/contributed capital, dividend policy, and disclosure quality: An international study. Journal of Banking \& Finance. 35(7), 1610-1625.

Caramelli, M., Briole, A.,2007. Employee stock ownership and job attitudes: Does culture matter? Human Resource Management Review. 17(3), 290-304.

Chang, S.,1990. Employee Stock Ownership Plans and Shareholder Wealth: An Empirical Investigation. Financial Management. 19(1), 48-58.

Cin, B., Smith, S. C., 2002. Employee Stock Ownership and Participation in South Korea: Incidence, Productivity Effects, and Prospects. Review of Development Economics. 6(2), 263-283.

Core, J. E., Guay, W. R., 2001. Stock option plans for non-executive employees. Journal of Financial Economics. 61(2), 253-287.

Claessens, S., Djankov, S., Lang, L. H., 2000. The separation of ownership and control in East Asian Corporations. Journal of Financial Economics. 58(1-2), 81-112.

Claessens, S., Djankov, S., Fan, J. P., Lang, L. H., 2002. Disentangling the Incentive and Entrenchment Effects of Large Shareholdings. The Journal of Finance. 57(6), 27412771.

Dhillon, U. S., Ramírez, G. G., 1994. Employee stock ownership and corporate control: An empirical study. Journal of Banking \& Finance. 18(1), 9-25.

Ding, D. K., Sun, Q., 2001. Causes and effects of employee stock option plans: Evidence from Singapore. Pacific-Basin Finance Journal. 9(5), 563-599.

Djankov, S., La Porta, R., Lopez-de-Silanes, F., Shleifer, A., 2008. The law and economics of self-dealing. Journal of Financial Economics. 88(3) 430-465.

Drakos, A., \& Bekiris, F. (2010). Corporate performance, managerial ownership and endogeneity: A simultaneous equations analysis for the Athens stock exchange. Research in International Business and Finance, 24, 24-38.

Eije, H. v., Megginson, W. L., 2008. Dividends and share repurchases in the European Union. Journal of Financial Economics. 89(2), 347-374.

European Commission., 2014. The Promotion of Employee Ownership and Participation.

Faccio, M., Lang, L. H., 2002. The ultimate ownership of Western European corporations. Journal of Financial Economics. 65(3), 365-395.

Furfine, C. H., 2001. Banks as monitors of other banks: Evidence from the overnight Federal Reserve fund market. Journal of Business. 74(1), 33 - 57.

Gamble, J. E., 2000. Management commitment to innovation and esop stock concentration. Journal of Business Venturing. 15(5-6), 433-447.

Gordon, L. A., Pound, J., 1990. ESOPs and corporate control. Journal of Financial Economics. 27(2), 525-555.

Hill, C. W., Snell, S. A., 1988. External Control, Corporate Strategy and Firm Performance in Research-intensive Industries. Strategic Management Journal. 9(6), 577 - 590.

Hofstede, G., 2001. Culture's consequences: Comparing values, behaviors, institutions, and organizations across nations. Thousand Oaks, California: Sage Publications.

Jensen, M. C., Meckling, W. H., 1976. Theory of the firm: Managerial behavior, agency costs and ownership structure. Journal of Financial Economics. 3(4), 305-360. 
John, K., Masi, S. D., Paci, A., 2016. Corporate governance in banks. Corporate Governance: An International Review. 24(3), 303-321.

Jones, D. C., Kato, T., 1995. The Productivity Effects of Employee Stock-Ownership Plans and Bonuses: Evidence from Japanese Panel Data. The American Economic Review. 85(3), 391-414.

Kolev, K., Thomas, J. K., Zhang, X. F., 2015. Non-Executive Employee Ownership and Corporate Risk. The Accounting Review. 90(1), 115-145.

La Porta, R., Lopez-de-Silanes, F., Shleifer, A., Vishny, R. W., 2007. Agency Problems and Dividend Policies around the World. The Journal of Finance. 55(1), 1-33.

La Porta, R., Lopezde-Silanes, F., Shleifer, A., 2002. Government Ownership of Banks. The Journal of Finance. 57(1), 265-301.

La Porta, R. L., Lopez-De-Silanes, F., Shleifer, A., 1999. Corporate Ownership Around the World. The Journal of Finance. 54(2), 471-517.

La Porta, R., Lopez-de-Silanes, F., Shleifer, A., Vishny, R. W., 1998. Law and Finance. Journal of Political Economy. 106(6), 1113-1155.

Laeven, L., 2013. Corporate governance: What's special about banks? Annual Review of Financial Economics. 5, 63-92.

Laeven, L., Levine, R., 2009. Bank governance, regulation and risk taking. Journal of Financial Economics. 93(2), 259-275.

Lampel, J., Bhalla, A., Jha, P., 2012. The employee ownership advantage: benefits and consequences. London: the Department for Business Innovation and Skills, Cass Business School.

Lepetit, L., Strobel, F., 2013. Bank insolvency risk and time-varying Z-score measures. Journal of International Financial Markets, Institutions and Money. 25, 73-87.

Lepetit, L., Strobel, F., 2015. Bank insolvency risk and Z-score measures: A refinement. Finance Research Letters. 13, 214-224.

Lepetit, L., Meslier, C., Wardhana, L. I., 2017. Reducing agency conflicts through bank dividend payout decisions: the role of opacity and ownership structure. Applied Economics. 49(49), 4999-5026.

Lepetit, L., Saghi-Zedek, N., Tarazi, A., 2015. Excess control rights, bank capital structure adjustments, and lending. Journal of Financial Economics. 115(3), 574-591.

Levine, R., 2004. The corporate governance of banks: A concise discussion of concepts and evidence. World Bank Research, 3404.

Li, K., Zhao, X., 2008. Asymmetric Information and Dividend Policy. Financial Management. 37(4), 673-694.

Morgan, D. P., 2002. Rating Banks: Risk and Uncertainty in an Opaque Industry. American Economic Review. 92(4), 874-888.

Nelson, D., Yackee, S. W., 2012. Lobbying Coalitions and Government Policy Change: An Analysis of Federal Agency Rulemaking. The Journal of Politics. 74(2), 339-353.

Oyer, P., Schaefer, S., 2005. Why do some firms give stock options to all employees?: An empirical examination of alternative theories. Journal of Financial Economics. 76(1), 99-133.

Park, S., Song, M. H., 1995. Employee Stock Ownership Plans, Firm Performance, and Monitoring by Outside Blockholders. Financial Management. 24(4), 52-65.

Shleifer, A., Vishny, R. W., 1997. A Survey of Corporate Governance. The Journal of Finance. 52(2), 737-783.

Yackee, S. W., 2012. The Politics of Ex Parte Lobbying: Pre-Proposal Agenda Building and Blocking during Agency Rulemaking. Journal of Public Administration Research and Theory. 22(2), 373-393. 
Table 1: Definitions, data sources and summary statistics for variables

\begin{tabular}{|c|c|c|c|c|c|c|c|}
\hline $\begin{array}{l}\text { Variable } \\
\text { name }\end{array}$ & Definition & Source & Min & Max & Median & Mean & Std. Dev. \\
\hline \multicolumn{8}{|c|}{ The dependent variable } \\
\hline D_ESOP & $\begin{array}{l}\text { The dummy variable equals one if bank employees (top managers } \\
\text { with/without selected employees) are granted shares or share } \\
\text { options through employee share ownership or employee share } \\
\text { options schemes in the year } 2015 \text {, and equals } 0 \text { otherwise. }\end{array}$ & Annual reports & 0 & 1 & 1 & 0.56 & 0.49 \\
\hline \multicolumn{8}{|c|}{ The variables of interest } \\
\hline Country Index & $\begin{array}{l}\text { Country Index = Legal index }+ \text { Fiscal index } \\
\text { Country Index measures the total supportive policies of a } \\
\text { country to promote Employee Share Ownership Programs. It } \\
\text { varies from } 0 \text { to } 7 . \text { The higher the index is, the more the } \\
\text { supportive policies are created to promote Employee Share } \\
\text { Ownership Programs. }\end{array}$ & & 1 & 7 & 4 & 3.59 & 2.09 \\
\hline Legal index & $\begin{array}{l}\text { Measure of the legal framework regarding the implementation } \\
\text { of ESOP. The Legal index varies from } 0 \text { to } 3 \text {. It equals to } 0 \text { if a } \\
\text { country has no systematic regulation of employee financial } \\
\text { participation programs and its general regulations neither } \\
\text { promote nor inhibit the development of employee share } \\
\text { ownership programs. It equals } 3 \text { if a country has a systematic } \\
\text { regulation of more than one aspects of employee share } \\
\text { ownership programs (usually tax and company law). }\end{array}$ & $\begin{array}{l}\text { The report "The promotion } \\
\text { of employee ownership } \\
\text { and participation" of the } \\
\text { European Commission, } \\
\text { published in October } \\
2014 \text {. }\end{array}$ & 0 & 3 & 2 & 1.85 & 0.75 \\
\hline Fiscal index & $\begin{array}{l}\text { Measure of tax and financial incentives for companies and } \\
\text { employees participating in employee share ownership programs. } \\
\text { The Fiscal index varies from } 0 \text { to } 4 \text {. It equals } 0 \text { if a country has no } \\
\text { special tax incentives and its general system of taxation neither } \\
\text { promotes nor inhibits the development of employees. It equals } 4 \\
\text { if a country has effective tax incentives and, additionally, other } \\
\text { instruments of fiscal support for employee share ownership } \\
\text { programs. }\end{array}$ & $\begin{array}{l}\text { The report "The promotion } \\
\text { of employee ownership } \\
\text { and participation" of the } \\
\text { European Commission, } \\
\text { published in October } \\
2014 \text {. }\end{array}$ & 0 & 4 & 2 & 1.74 & 1.41 \\
\hline
\end{tabular}




\section{The instrumental variable}

\begin{tabular}{llllll}
\hline Labor-support- & The total number of political parties in parliament supporting Government websites and & 2 & 8 & 3 & 4.16 \\
parties & labor rights, including socialist (except the green party), internet & 2.09
\end{tabular}

parties labor rights, including socialist (except the green party), internet communist and labor parties.

\section{Control variables}

\begin{tabular}{|c|c|c|c|c|c|c|c|}
\hline Size & Natural logarithm of Total Assets. & Bankscope & 12.11 & 21.64 & 17.26 & 17.15 & 2.70 \\
\hline Equity ratio & Total equity divided by total assets. & Bankscope & 0.03 & 0.32 & 0.07 & 0.08 & 0.05 \\
\hline $\mathrm{ROE}$ & Return on equity ratio. & Bankscope & -0.89 & 0.27 & 0.06 & 0.03 & 0.16 \\
\hline $\begin{array}{l}\text { Growth of total } \\
\text { assets }\end{array}$ & $\begin{array}{l}\text { The growth of total assets }=(\text { Total assets in } 2014-\text { Total assets } \\
\text { in } 2013) \text { /Total assets in } 2013 .\end{array}$ & Bankscope & -0.35 & 0.82 & -0.09 & -0.06 & 0.15 \\
\hline $\begin{array}{l}\text { Deposit over } \\
\text { total assets }\end{array}$ & Total deposits divided by total assets. & Bankscope & 0.03 & 0.93 & 0.73 & 0.69 & 0.17 \\
\hline Opacity & $\begin{array}{l}\text { Measure of four components of opacity: (EF) measures the } \\
\text { disconnection between insiders' and outsiders' information } \\
\text { about firms' financial condition by computing the analyst } \\
\text { forecast error; (EM) measures accounting opacity and is } \\
\text { computed by the degree of earnings management of banks; } \\
\text { (MF) is the negative of the ratio of short term and long term } \\
\text { market funding to total assets measuring banks' exposure to the } \\
\text { market; (Loan) loans in total assets. Then, each component is } \\
\text { associated with the value of } 1 \text { to } 10 \text { corresponding to the decile } \\
\text { of } 1 \text { to } 10 \text {. After that, we sum up the four proxies, then divide it } \\
\text { by four to scale the composite index. This index ranges from } 1 \\
\text { to } 10 \text {. The most transparent bank has a value of } 1 \text { and the most } \\
\text { opaque bank has a value of } 10 \text {. }\end{array}$ & Lepetit et al. (2017) & 1.5 & 9.5 & 5.5 & 5.47 & 1.63 \\
\hline D_Opacity & $\begin{array}{l}\text { The dummy variable } D \_ \text {Opacity takes the value one if the } \\
\text { bank has a degree of opacity higher than the median of the } \\
\text { sample; it takes the value zero otherwise. }\end{array}$ & & 0 & 1 & 0 & 0.49 & 0.50 \\
\hline
\end{tabular}




\begin{tabular}{|c|c|c|c|c|c|c|c|}
\hline \multirow[t]{2}{*}{ Z-Score } & $\begin{array}{l}\text { Measure of bank's solvability. Z-score is computed by three- } \\
\text { year moving window to compute the standard deviation of asset } \\
\text { returns for each bank each year. A higher Z-score indicates that } \\
\text { a bank has a lower risk of insolvability. } \\
\text { Formula to calculate: } \\
\text { Z-Score }=\frac{\mu_{R O A}(3)+E Q \_T A}{\delta_{R O A}(3)}\end{array}$ & $\begin{array}{l}\text { Laeven and Levine (2009); } \\
\text { Lepetit and Strobel (2013); } \\
\text { and Lepetit and Strobel } \\
(2015) \text {. }\end{array}$ & -0.22 & 6.28 & 3.66 & 3.51 & 1.50 \\
\hline & $\begin{array}{l}\text { Where } \mu_{R O A}(3) \text { : moving mean for } 3 \text { observations of ROA } \\
\text { EQ_TA: current value of capital-asset ratio } \\
\delta_{R O A}(3) \text { : moving standard deviation for } 3 \text { observations of ROA }\end{array}$ & & & & & & \\
\hline D_Controlling & $\begin{array}{l}\text { The dummy takes the value of one if the bank has at least one } \\
\text { controlling shareholder; } 0 \text { otherwise. We follow the existing } \\
\text { literature (La Porta et al., 1999; Claessens et al., 2000; Faccio \& } \\
\text { Lang, 2002) by using the controlling threshold of 20\% of } \\
\text { outstanding shares to distinguish between widely-held and } \\
\text { closely-held banks. If a bank has at least one shareholder who } \\
\text { owns at least 20\% of its outstanding shares, it will be classified } \\
\text { as a closely-held bank; it will be classified as a widely-held } \\
\text { bank, otherwise. }\end{array}$ & Bankscope & 0 & 1 & 1 & 0.52 & 0.50 \\
\hline RADI & $\begin{array}{l}\text { This index measures the level of shareholder rights for each } \\
\text { country, i.e. the legal protection of shareholders against } \\
\text { expropriation by managers through several measures; it takes } 1 \\
\text { for each following component of the commercial laws of a } \\
\text { country including (1) vote by mail is allowed; (2) shareholders } \\
\text { are not required to deposit shares before annual shareholders' } \\
\text { meeting; (3) cumulative voting is allowed; (4) minority } \\
\text { shareholders have legal mechanisms against perceived } \\
\text { oppression by the board; (5) shareholders have pre-emptive } \\
\text { rights that can be waived only by shareholders' vote, and (6) the } \\
\text { minimum percentage of share capital that allows a shareholder } \\
\text { to call for a special shareholders' meeting is no more than } 10 \% \text {. } \\
\text { The shareholder protection index (RADIj) varies from } 0 \text { (for } \\
\text { weak protection countries) to } 6 \text { (for strong protection countries). }\end{array}$ & $\begin{array}{l}\text { Porta et al. (1998) and } \\
\text { revised by Djankov et } \\
\text { al. }(2008)\end{array}$ & 2 & 5 & 3.5 & 3.43 & 1.00 \\
\hline
\end{tabular}




\begin{tabular}{|c|c|c|c|c|c|c|}
\hline D_RADI & $\begin{array}{l}\text { The dummy variable } D \_R A D I \text { takes the value one if the } \\
\text { level of shareholder protection of a country is lower than } \\
\text { the median of the sample; it takes the value zero otherwise. }\end{array}$ & 0 & 1 & 1 & 0.60 & 0.49 \\
\hline Individualism & $\begin{array}{l}\text { The individualism/collectivism dichotomy personifies the } \\
\text { distinction between collective (group-based) and individual- } \\
\text { based decision making. When individualism is low, there is } \\
\text { priority for group effort to achieve success. When it is high, } \\
\text { there is priority for individual needs and achievements. } \\
\text { Individuals in an individualistic culture are likely to challenge } \\
\text { authority and encourage a reduction of power differences } \\
\text { between management and employees. However, individuals in a } \\
\text { collectivist culture are likely to protect the well-being of the } \\
\text { group and less challenge managers. We use the individualism } \\
\text { score of each country constructed by Hofstede (2001). The } \\
\text { higher the score is, the more individualism the country is. }\end{array}$ & 27 & 89 & 71 & 68.66 & 13.52 \\
\hline
\end{tabular}


Table 2: Is the national supportive policy effective to promote employee share ownership programs?

This table reports regression estimates models where the dependent variable is the dummy variable D_ESOP. Column 1 reports regression estimates for the probit model without using instrument variable. Columns 2 and 3 report 1st and 2nd stage ivprobit regression estimates obtained when the national supportive policy (Country index) is instrumented with the number of labor-support-parties presented in parliament. Column 4 reports the marginal effects. All variables definitions are in Table 1. For main results: the corresponding t-statistics are reported in parentheses. For weak instrument robust tests: pvalues in parentheses. With *, **, and $* * *$ denoting significance at $10 \%, 5 \%$ and $1 \%$ levels.

\begin{tabular}{|c|c|c|c|c|}
\hline & $\begin{array}{l}\text { (1) } \\
\text { Probit }\end{array}$ & $\begin{array}{c}\text { (2) } \\
\text { ivprobit } \\
\text { 1st Stage }\end{array}$ & $\begin{array}{c}\text { (3) } \\
\text { ivprobit } \\
\text { 2nd Stage }\end{array}$ & $\begin{array}{c}(4) \\
\text { ivprobit } \\
\text { Marginal Effects }\end{array}$ \\
\hline Country index & $\begin{array}{c}0.444 * * * \\
(4.63)\end{array}$ & & & \\
\hline Instrumented Country index & & & $\begin{array}{c}0.579 * * \\
(2.58)\end{array}$ & $\begin{array}{c}0.111 * * * \\
(0.0176)\end{array}$ \\
\hline Labor-support-parties & & $\begin{array}{c}0.414 * * * \\
(4.19)\end{array}$ & & \\
\hline Size_lag(1) & $\begin{array}{c}0.0771 \\
(0.76)\end{array}$ & $\begin{array}{c}0.285 * * * \\
(2.73)\end{array}$ & $\begin{array}{l}0.0215 \\
(0.16)\end{array}$ & $\begin{array}{l}0.00410 \\
(0.0259)\end{array}$ \\
\hline Equity_TA_lag(1) & $\begin{array}{l}-2.303 \\
(-0.58)\end{array}$ & $\begin{array}{c}9.608^{* *} \\
(2.19)\end{array}$ & $\begin{array}{l}-4.213 \\
(-0.85)\end{array}$ & $\begin{array}{c}-0.805 \\
(0.854)\end{array}$ \\
\hline ROE_lag(1) & $\begin{array}{l}0.584 \\
(0.42)\end{array}$ & $\begin{array}{l}-0.398 \\
(-0.32)\end{array}$ & $\begin{array}{l}0.599 \\
(0.42)\end{array}$ & $\begin{array}{c}0.114 \\
(0.276)\end{array}$ \\
\hline Growth_TA_lag(1) & $\begin{array}{c}-0.0728 \\
(-0.06)\end{array}$ & $\begin{array}{l}1.490 \\
(1.29)\end{array}$ & $\begin{array}{l}-0.265 \\
(-0.22)\end{array}$ & $\begin{array}{l}-0.0506 \\
(0.224)\end{array}$ \\
\hline Deposit_TA_lag(1) & $\begin{array}{l}-1.941 \\
(-1.45)\end{array}$ & $\begin{array}{l}1.150 \\
(0.94)\end{array}$ & $\begin{array}{l}-2.219 \\
(-1.58)\end{array}$ & $\begin{array}{c}-0.424 * \\
(0.250)\end{array}$ \\
\hline Opacity_lag(1) & $\begin{array}{c}-0.0219 \\
(-0.17)\end{array}$ & $\begin{array}{c}-0.262 * * \\
(-2.08)\end{array}$ & $\begin{array}{c}0.0176 \\
(0.12)\end{array}$ & $\begin{array}{l}0.00336 \\
(0.0267)\end{array}$ \\
\hline Z-Score_lag(1) & $\begin{array}{l}0.102 \\
(0.83)\end{array}$ & $\begin{array}{l}0.175 \\
(1.30)\end{array}$ & $\begin{array}{c}0.0965 \\
(0.77)\end{array}$ & $\begin{array}{c}0.0184 \\
(0.0244)\end{array}$ \\
\hline D_Controlling & $\begin{array}{l}-0.331 \\
(-0.92)\end{array}$ & $\begin{array}{l}0.456 \\
(1.31)\end{array}$ & $\begin{array}{l}-0.380 \\
(-1.02)\end{array}$ & $\begin{array}{l}-0.0726 \\
(0.0688)\end{array}$ \\
\hline RADI & $\begin{array}{c}-0.443 * * \\
(-2.44)\end{array}$ & $\begin{array}{c}0.652 * * * \\
(2.98)\end{array}$ & $\begin{array}{c}-0.490 * * \\
(-2.45)\end{array}$ & $\begin{array}{c}-0.0935 * * * \\
(0.0330)\end{array}$ \\
\hline Individualism & $\begin{array}{c}0.0200 \\
(1.45)\end{array}$ & $\begin{array}{c}0.00846 \\
(0.56)\end{array}$ & $\begin{array}{c}0.0153 \\
(1.00)\end{array}$ & $\begin{array}{c}0.00293 \\
(0.00322)\end{array}$ \\
\hline Observations & 103 & 103 & 103 & 103 \\
\hline \multicolumn{5}{|c|}{ Weak instrument robust tests and confidence sets for ivprobit } \\
\hline $\begin{array}{l}\text { Anderson-Rubin test } \\
\quad \text { (p-value) } \\
\text { Wald test } \\
\text { (p-value) }\end{array}$ & & & $\begin{array}{c}5.74 \\
(0.0166) \\
6.64 \\
(0.0100) \\
\end{array}$ & \\
\hline
\end{tabular}


Table 3: Which types of supportive policies matter?

This table reports regression estimates of the ivprobit models where the dependent variable is $D \_E S O P$. Columns 1 and 2 report 1st and 2nd stage ivprobit regression estimates obtained when the Legal index is instrumented with the number of labor-support-parties presented in parliament. Columns 3 and 4 report 1st and 2nd stage ivprobit regression estimates obtained when the Fiscal index is instrumented with the number of labor-support-parties presented in parliament. All variables definitions are in Table 1. For main results: the corresponding t-statistics are reported in parentheses. For weak instrument robust tests: p-values are in parentheses. With *, **, and *** denoting significance at $10 \%, 5 \%$ and $1 \%$ levels.

\begin{tabular}{|c|c|c|c|c|}
\hline Dependent variable: & & D_ESOP & & D_ESOP \\
\hline & $\begin{array}{c}\text { (1) } \\
\text { ivprobit } \\
\text { 1st Stage }\end{array}$ & $\begin{array}{c}(2) \\
\text { ivprobit } \\
\text { 2nd Stage }\end{array}$ & $\begin{array}{c}(3) \\
\text { ivprobit } \\
\text { 1st Stage }\end{array}$ & $\begin{array}{c}\text { (4) } \\
\text { ivprobit } \\
\text { 2nd Stage }\end{array}$ \\
\hline Instrumented Legal index & & $\begin{array}{c}2.275^{* *} \\
(2.47)\end{array}$ & & \\
\hline Instrumented Fiscal index & & & & $\begin{array}{c}0.756^{* *} \\
(2.54)\end{array}$ \\
\hline Labor-support-parties & $\begin{array}{c}0.109 * * * \\
(3.01)\end{array}$ & & $\begin{array}{c}0.305^{* * * *} \\
(4.58)\end{array}$ & \\
\hline Size_lag(1) & $\begin{array}{c}0.0791 * * \\
(2.07)\end{array}$ & $\begin{array}{c}-0.0196 \\
(-0.14)\end{array}$ & $\begin{array}{c}0.206 * * * \\
(2.93)\end{array}$ & $\begin{array}{c}0.0375 \\
(0.29)\end{array}$ \\
\hline Equity_TA_lag(1) & $\begin{array}{c}3.981 * * \\
(2.48)\end{array}$ & $\begin{array}{l}-8.378 \\
(-1.33)\end{array}$ & $\begin{array}{c}5.628 * \\
(1.90)\end{array}$ & $\begin{array}{l}-2.588 \\
(-0.56)\end{array}$ \\
\hline ROE_lag(1) & $\begin{array}{c}0.0118 \\
(0.03)\end{array}$ & $\begin{array}{l}0.371 \\
(0.25)\end{array}$ & $\begin{array}{l}-0.409 \\
(-0.49)\end{array}$ & $\begin{array}{l}0.639 \\
(0.44)\end{array}$ \\
\hline Growth_TA_lag(1) & $\begin{array}{l}0.412 \\
(0.98)\end{array}$ & $\begin{array}{l}-0.338 \\
(-0.27)\end{array}$ & $\begin{array}{l}1.078 \\
(1.39)\end{array}$ & $\begin{array}{l}-0.219 \\
(-0.19)\end{array}$ \\
\hline Deposit_TA_lag(1) & $\begin{array}{l}0.230 \\
(0.51)\end{array}$ & $\begin{array}{l}-2.304 \\
(-1.53)\end{array}$ & $\begin{array}{l}0.920 \\
(1.12)\end{array}$ & $\begin{array}{l}-2.048 \\
(-1.51)\end{array}$ \\
\hline Opacity_lag(1) & $\begin{array}{c}-0.144 * * * \\
(-3.13)\end{array}$ & $\begin{array}{l}0.198 \\
(1.05)\end{array}$ & $\begin{array}{l}-0.118 \\
(-1.39)\end{array}$ & $\begin{array}{c}-0.0433 \\
(-0.33)\end{array}$ \\
\hline Z-Score_lag(1) & $\begin{array}{c}0.0646 \\
(1.31)\end{array}$ & $\begin{array}{c}0.0464 \\
(0.34)\end{array}$ & $\begin{array}{l}0.111 \\
(1.21)\end{array}$ & $\begin{array}{l}0.110 \\
(0.88)\end{array}$ \\
\hline D_Controlling & $\begin{array}{c}0.0808 \\
(0.63)\end{array}$ & $\begin{array}{l}-0.334 \\
(-0.86)\end{array}$ & $\begin{array}{l}0.375 \\
(1.59)\end{array}$ & $\begin{array}{l}-0.389 \\
(-1.06)\end{array}$ \\
\hline RADI & $\begin{array}{c}0.0996 \\
(1.25)\end{array}$ & $\begin{array}{c}-0.356^{*} \\
(-1.83)\end{array}$ & $\begin{array}{c}0.552 * * * \\
(3.74)\end{array}$ & $\begin{array}{c}-0.532 * * \\
(-2.56)\end{array}$ \\
\hline Individualism & $\begin{array}{c}0.0132 * * \\
(2.39) \\
\end{array}$ & $\begin{array}{c}-0.0134 \\
(-0.60) \\
\end{array}$ & $\begin{array}{c}-0.00472 \\
(-0.46) \\
\end{array}$ & $\begin{array}{c}0.0258^{*} \\
(1.79) \\
\end{array}$ \\
\hline Observations & & 103 & & 103 \\
\hline Anderson-Rubin test & & $\begin{array}{c}5.99 \\
(0.0144)\end{array}$ & & $\begin{array}{c}5.65 \\
(0.0174)\end{array}$ \\
\hline Wald test & & $\begin{array}{c}6.10 \\
(0.0135)\end{array}$ & & $\begin{array}{c}6.47 \\
(0.0110)\end{array}$ \\
\hline
\end{tabular}


Table 4: Ownership structure and effectiveness of national supportive measures

This table reports regression estimates of the 2nd stage of the ivprobit models where the dependent variable is $D \_E S O P$. Colum 1, 2, 3 report the results when the Country index, the Legal index and the Fiscal index is instrumented with the number of labor-support-parties, respectively.

\begin{tabular}{|c|c|c|c|}
\hline Dependent variable: & D_ESOP & D_ESOP & D_ESOP \\
\hline & $\begin{array}{c}(1) \\
\text { ivprobit } \\
\text { 2nd Stage }\end{array}$ & $\begin{array}{c}(2) \\
\text { ivprobit } \\
\text { 2nd Stage }\end{array}$ & $\begin{array}{c}\text { (3) } \\
\text { ivprobit } \\
\text { 2nd Stage }\end{array}$ \\
\hline Instrumented Country index (b1) & $\begin{array}{c}0.463 * * * \\
(4.68)\end{array}$ & & \\
\hline Instrumented Country index * D_Controlling (b2) & $\begin{array}{l}-0.242 \\
(-1.08)\end{array}$ & & \\
\hline Instrumented Legal index (b1) & & $\begin{array}{c}1.274 * * * \\
(4.30)\end{array}$ & \\
\hline Instrumented Legal index * D_Controlling (b2) & & $\begin{array}{l}-0.352 \\
(-0.52)\end{array}$ & \\
\hline Instrumented Fiscal index (b1) & & & $\begin{array}{c}0.652 * * * \\
(4.63)\end{array}$ \\
\hline Instrumented Fiscal index * D_Controlling (b2) & & & $\begin{array}{l}-0.401 \\
(-1.28)\end{array}$ \\
\hline D_Controlling & $\begin{array}{l}0.540 \\
(0.61)\end{array}$ & $\begin{array}{l}0.353 \\
(0.28)\end{array}$ & $\begin{array}{l}0.377 \\
(0.57)\end{array}$ \\
\hline Size_lag(1) & $\begin{array}{l}0.101 \\
(0.96)\end{array}$ & $\begin{array}{l}0.100 \\
(0.96)\end{array}$ & $\begin{array}{l}0.110 \\
(1.05)\end{array}$ \\
\hline Equity_TA_lag(1) & $\begin{array}{l}-0.954 \\
(-0.23)\end{array}$ & $\begin{array}{l}-2.246 \\
(-0.50)\end{array}$ & $\begin{array}{l}-0.128 \\
(-0.03)\end{array}$ \\
\hline ROE_lag(1) & $\begin{array}{l}0.557 \\
(0.39)\end{array}$ & $\begin{array}{l}0.482 \\
(0.36)\end{array}$ & $\begin{array}{l}0.574 \\
(0.40)\end{array}$ \\
\hline Growth_TA_lag(1) & $\begin{array}{l}0.185 \\
(0.15)\end{array}$ & $\begin{array}{l}0.163 \\
(0.15)\end{array}$ & $\begin{array}{l}0.240 \\
(0.20)\end{array}$ \\
\hline Deposit_TA_lag(1) & $\begin{array}{l}-1.623 \\
(-1.22)\end{array}$ & $\begin{array}{l}-1.729 \\
(-1.23)\end{array}$ & $\begin{array}{l}-1.454 \\
(-1.15)\end{array}$ \\
\hline Opacity_lag(1) & $\begin{array}{c}-0.0766 \\
(-0.56)\end{array}$ & $\begin{array}{c}0.00720 \\
(0.05)\end{array}$ & $\begin{array}{l}-0.111 \\
(-0.85)\end{array}$ \\
\hline Z-Score_lag(1) & $\begin{array}{l}0.119 \\
(0.95)\end{array}$ & $\begin{array}{l}0.0836 \\
(0.67)\end{array}$ & $\begin{array}{l}0.125 \\
(1.01)\end{array}$ \\
\hline RADI & $\begin{array}{c}-0.394^{* * *} \\
(-2.11)\end{array}$ & $\begin{array}{c}-0.346^{* *} \\
(-1.97)\end{array}$ & $\begin{array}{c}-0.409^{* *} \\
(-2.15)\end{array}$ \\
\hline Individualism & $\begin{array}{c}0.0255^{*} \\
(1.69)\end{array}$ & $\begin{array}{l}0.0105 \\
(0.64)\end{array}$ & $\begin{array}{c}0.0327^{* *} \\
(2.20)\end{array}$ \\
\hline Observation & 103 & 103 & 103 \\
\hline \multicolumn{4}{|l|}{ Wald test } \\
\hline $\mathrm{b} 1+\mathrm{b} 2=0$ & $\begin{array}{c}0.221 \\
(0.952)\end{array}$ & $\begin{array}{c}0.922 \\
(1.630)\end{array}$ & $\begin{array}{c}0.251 \\
(0.661)\end{array}$ \\
\hline
\end{tabular}

The t-statistics are in parentheses, with *,**, and *** denoting significance at $10 \%, 5 \%$ and $1 \%$ levels. 
Table 5: Ownership structure, degrees of opacity, and effectiveness of national supportive measures

This table reports regression estimates of the 2nd stage of the ivprobit models where the dependent variable is D_ESOP. Colum 1, 2, 3 report the results when Country index, Legal index and Fiscal index is instrumented with the number of labor-support-parties, respectively. We conduct the triple-interaction between the indices; D_Controlling and D_Opacity.

\begin{tabular}{|c|c|c|c|}
\hline Dependent variable: & D_ESOP & D_ESOP & D_ESOP \\
\hline & $\begin{array}{c}\text { (1) } \\
\text { ivprobit } \\
\text { 2nd Stage }\end{array}$ & $\begin{array}{c}(2) \\
\text { ivprobit } \\
\text { 2nd Stage }\end{array}$ & $\begin{array}{c}(3) \\
\text { ivprobit } \\
\text { 2nd Stage }\end{array}$ \\
\hline IV_Country index (b1) & $\begin{array}{c}1.791 * * * \\
(3.27)\end{array}$ & & \\
\hline IV_Country index *D_Controlling (b2) & $\begin{array}{c}-1.237 * * * \\
(-2.71)\end{array}$ & & \\
\hline IV_Country index * D_Opacity (b3) & $\begin{array}{c}-0.928 * * \\
(-1.99)\end{array}$ & & \\
\hline IV_Country index * D_Controlling * D_Opacity (b4) & $\begin{array}{c}0.622 * * \\
(2.36)\end{array}$ & & \\
\hline IV_Legal index (b1) & & $\begin{array}{c}4.081 * * * \\
(2.75)\end{array}$ & \\
\hline IV_Legal index * D_Controlling (b2) & & $\begin{array}{c}-2.208 * \\
(-1.79)\end{array}$ & \\
\hline IV_Legal index * D_Opacity (b3) & & $\begin{array}{l}-1.463 \\
(-1.31)\end{array}$ & \\
\hline IV_Legal index * D_Controlling * D_Opacity (b4) & & $\begin{array}{c}1.003 * * \\
(2.29)\end{array}$ & \\
\hline IV_Fiscal index (b1) & & & $\begin{array}{c}2.970 * * * \\
(2.94)\end{array}$ \\
\hline IV_Fiscal index * D_Controlling (b2) & & & $\begin{array}{c}-2.266 * * * \\
(-2.59)\end{array}$ \\
\hline IV_Fiscal index * D_Opacity (b3) & & & $\begin{array}{c}-1.821^{* *} \\
(-1.96)\end{array}$ \\
\hline IV_Fiscal index * D_Controlling * D_Opacity (b4) & & & $\begin{array}{c}1.431 * * \\
(2.14)\end{array}$ \\
\hline D_Opacity & $\begin{array}{l}2.106 \\
(1.64)\end{array}$ & $\begin{array}{l}2.142 \\
(1.19)\end{array}$ & $\begin{array}{l}1.535 \\
(1.57)\end{array}$ \\
\hline Control variables & Yes & Yes & Yes \\
\hline Observation & 103 & 103 & 103 \\
\hline
\end{tabular}

The t-statistics are in parentheses, with *, **, and *** denoting significance at $10 \%, 5 \%$ and $1 \%$ levels. 
Table 6: Ownership structure, degrees of opacity, and effectiveness of national supportive measures, Wald test from Table 5

Country Legal index Fiscal index

Support index

\begin{tabular}{lccc}
\hline Widely-held banks, low opacity & & & \\
\hline $\mathrm{b} 1=0$ & $\begin{array}{c}1.791^{* * *} \\
(3.27)\end{array}$ & $\begin{array}{c}4.081^{* * *} \\
(2.75)\end{array}$ & $\begin{array}{c}2.970^{* * * *} \\
(2.94)\end{array}$ \\
\hline Widely-held banks, high opacity & & & \\
\hline $\mathrm{b} 1+\mathrm{b} 3=0$ & $\begin{array}{c}0.862^{* * *} \\
(6.731)\end{array}$ & $\begin{array}{c}2.617^{* *} \\
(4.882)\end{array}$ & $\begin{array}{c}1.148^{* * *} \\
(6.884)\end{array}$ \\
\hline Closely-held banks, low opacity & & & \\
\hline b1 + b2 = & $\begin{array}{c}0.553^{* *} \\
(4.288)\end{array}$ & $\begin{array}{c}1.873^{* *} \\
(5.791)\end{array}$ & $\begin{array}{c}0.704^{*} \\
(3.216)\end{array}$ \\
\hline Closely-held banks, high opacity & & & \\
\hline b1 + b2 + b3 + b4 = 0 & $\begin{array}{c}0.247 \\
(0.663)\end{array}$ & $\begin{array}{c}1.412 \\
(2.045)\end{array}$ & $\begin{array}{c}0.313 \\
(0.537)\end{array}$ \\
\hline
\end{tabular}

The t-statistics are in parentheses, with *,**, and *** denoting significance at $10 \%, 5 \%$ and $1 \%$ levels. 
Table 7: Ownership structure, levels of of shareholder protection, and effectiveness of national supportive measures

This table reports regression estimates of the 2 nd stage of the ivprobit models where the dependent variable is D_ESOP. Colum 1, 2, 3 report the results when Country index, Legal index and Fiscal index is instrumented with the number of labor-support-parties, respectively. We conduct the triple-interaction between the indices, D_Controlling, and D_RADI.

\begin{tabular}{|c|c|c|c|}
\hline Dependent variable: & $\begin{array}{c}\text { ESOP } \\
(1) \\
\text { ivprobit } \\
\text { 2nd Stage } \\
\end{array}$ & $\begin{array}{c}\text { ESOP } \\
(2) \\
\text { ivprobit } \\
\text { 2nd Stage }\end{array}$ & $\begin{array}{c}\text { ESOP } \\
(3) \\
\text { ivprobit } \\
\text { 2nd Stage }\end{array}$ \\
\hline IV_Country index (b1) & $\begin{array}{c}1.591 * * * \\
(3.61)\end{array}$ & & \\
\hline IV_Country index *D_Controlling (b2) & $\begin{array}{c}-0.614 * * \\
(-1.96)\end{array}$ & & \\
\hline IV_Country index *D_RADI (b3) & $\begin{array}{l}-0.570 \\
(-1.13)\end{array}$ & & \\
\hline IV_Country index $*$ D_Controlling $*$ D_RADI (b4) & $\begin{array}{l}-0.238 \\
(-0.96)\end{array}$ & & \\
\hline IV_Legal index (b1) & & $\begin{array}{c}4.814 * * * \\
(2.96)\end{array}$ & \\
\hline IV_Legal index * D_Controlling (b2) & & $\begin{array}{l}-1.383 \\
(-1.36)\end{array}$ & \\
\hline IV_Legal index * D_RADI (b3) & & $\begin{array}{l}-1.441 \\
(-1.05)\end{array}$ & \\
\hline IV_Legal index * D_Controlling * D_RADI (b4) & & $\begin{array}{l}-0.313 \\
(-0.69)\end{array}$ & \\
\hline IV_Fiscal index (b1) & & & $\begin{array}{c}2.055^{* * * *} \\
(3.74)\end{array}$ \\
\hline IV_Fiscal index * D_Controlling (b2) & & & $\begin{array}{c}-0.795^{*} \\
(-1.96)\end{array}$ \\
\hline IV_Fiscal index * D_RADI (b3) & & & $\begin{array}{l}-0.632 \\
(-0.91)\end{array}$ \\
\hline IV_Fiscal index * D_Controlling * D_RADI (b4) & & & $\begin{array}{l}-0.543 \\
(-1.16)\end{array}$ \\
\hline D_RADI & $\begin{array}{c}-4.229 * * \\
(-2.48)\end{array}$ & $\begin{array}{l}-4.100^{*} \\
(-1.76)\end{array}$ & $\begin{array}{c}3.498 * * * \\
(2.92)\end{array}$ \\
\hline D_Controlling & $\begin{array}{l}1.881 \\
(1.60)\end{array}$ & $\begin{array}{l}2.216 \\
(1.25) \\
\end{array}$ & $\begin{array}{l}1.107 \\
(1.41)\end{array}$ \\
\hline Control variables & Yes & Yes & Yes \\
\hline Observation & 103 & 103 & 103 \\
\hline
\end{tabular}

The t-statistics are in parentheses, with *, **, and *** denoting significance at $10 \%, 5 \%$ and $1 \%$ levels. 
Table 8: Ownership structure, levels of of shareholder protection, and effectiveness of national supportive measures, Wald test from Table 7

Country Legal index Fiscal index

Support index

Widely-held banks, low shareholder protection

\begin{tabular}{lccc}
\hline $\mathrm{b} 1+\mathrm{b} 3=0$ & $\begin{array}{c}1.022^{* *} \\
(5.761)\end{array}$ & $\begin{array}{c}3.372 * * * \\
(7.395)\end{array}$ & $\begin{array}{c}1.423 * * \\
(5.395)\end{array}$ \\
\hline Widely-held banks, high shareholder protection & & & \\
\hline b1 = & $\begin{array}{c}1.591 * * * \\
(3.61)\end{array}$ & $\begin{array}{c}4.814^{* * *} \\
(2.96)\end{array}$ & $\begin{array}{c}2.055^{* * *} \\
(3.74)\end{array}$ \\
\hline Closely-held banks, low shareholder protection & & & \\
\hline b1 + b2 + b3 + b4 = & $\begin{array}{c}0.169 \\
(0.499)\end{array}$ & $\begin{array}{c}1.676 \\
(0.0492)\end{array}$ & $\begin{array}{c}0.0841 \\
(0.0635)\end{array}$ \\
\hline Closely-held banks, high shareholder protection & & & \\
\hline b1 + b2 = 0 & $\begin{array}{c}0.977 * * \\
(5.993)\end{array}$ & $\begin{array}{c}3.431 * * \\
(5.943)\end{array}$ & $\begin{array}{c}1.259 * * \\
(6.107)\end{array}$ \\
\hline
\end{tabular}

The t-statistics are in parentheses, with *, **, and *** denoting significance at $10 \%, 5 \%$ and $1 \%$ levels. 


\section{Appendix A}

Table A.1: Number of banks with employee share ownership programs (ESOP) and values of the supportive measures indexes by country in 2015.

\begin{tabular}{|c|c|c|c|c|c|c|}
\hline & Country Name & $\begin{array}{c}\text { Total number } \\
\text { of banks }\end{array}$ & $\begin{array}{l}\text { Number of banks } \\
\text { having ESOP }\end{array}$ & Legal index & Fiscal index & Country index \\
\hline 1 & Austria & 6 & 3 & 2 & 3 & 5 \\
\hline 2 & Belgium & 2 & 0 & 2 & 2 & 4 \\
\hline 3 & Denmark & 22 & 1 & 1 & 0 & 1 \\
\hline 4 & Finland & 3 & 3 & 1 & 1 & 2 \\
\hline 5 & France & 4 & 3 & 2 & 3 & 5 \\
\hline 6 & Germany & 7 & 3 & 2 & 1 & 3 \\
\hline 7 & Greece & 5 & 1 & 1 & 1 & 2 \\
\hline 8 & Ireland & 2 & 0 & 2 & 3 & 5 \\
\hline 9 & Italy & 13 & 13 & 2 & 2 & 4 \\
\hline 10 & Netherlands & 4 & 3 & 2 & 0 & 2 \\
\hline 11 & Norway & 1 & 0 & 0 & 1 & 1 \\
\hline 12 & Portugal & 2 & 0 & 1 & 0 & 1 \\
\hline 13 & Spain & 7 & 5 & 2 & 3 & 5 \\
\hline 14 & Sweden & 3 & 2 & 1 & 0 & 1 \\
\hline 15 & Switzerland & 12 & 11 & 3 & 3 & 6 \\
\hline \multirow[t]{7}{*}{16} & United Kingdom & 10 & 10 & 3 & 4 & 7 \\
\hline & Total & 103 & 58 & & & \\
\hline & Average & & & 1.85 & 1.74 & 3.59 \\
\hline & Median & & & 2 & 2 & 4 \\
\hline & Min & & & 0 & 0 & 1 \\
\hline & Max & & & 3 & 4 & 7 \\
\hline & Std. Dev. & & & 0.759 & 1.414 & 2.093 \\
\hline
\end{tabular}

Table A.2: Statistic of banks having ESOP among widely- and closely-held banks.

\begin{tabular}{|c|c|c|}
\hline & Widely-held banks & Closely-held banks \\
\hline Number of banks & 49 & 54 \\
\hline \% of banks having ESOP by country & & \\
Mean & 53.06 & 59.25 \\
Min & 0 & 0 \\
Max & 100 & 100 \\
Std. & 50.42 & 49.59 \\
\hline
\end{tabular}




\section{Appendix B}

Matrix of correlations between control variables

\begin{tabular}{|c|c|c|c|c|c|c|c|c|c|c|}
\hline & Size & EQ_TA & ROE & Growth_TA & Deposit_TA & Opacity & ZScore & D_Controlling & RADI & Individualism \\
\hline Size & 1 & & & & & & & & & \\
\hline EQ_TA & $-0.586^{* * *}$ & 1 & & & & & & & & \\
\hline ROE & -0.0180 & 0.143 & 1 & & & & & & & \\
\hline Growth_TA & 0.0700 & -0.00585 & $0.229^{*}$ & 1 & & & & & & \\
\hline Deposit_TA & $-0.491^{* * *}$ & 0.102 & -0.0917 & $-0.249^{*}$ & 1 & & & & & \\
\hline Opacity & $-0.450^{* * *}$ & $0.360^{* * *}$ & $0.297^{* *}$ & 0.00625 & 0.103 & 1 & & & & \\
\hline ZScore & -0.0261 & $0.273^{* *}$ & $0.464^{* * *}$ & 0.123 & -0.0683 & 0.0624 & 1 & & & \\
\hline D_Controling & 0.0286 & 0.0970 & 0.0270 & 0.0188 & -0.0838 & -0.112 & 0.0369 & 1 & & \\
\hline RADI & 0.0225 & 0.113 & 0.186 & 0.150 & -0.0351 & 0.126 & 0.155 & -0.176 & 1 & \\
\hline Individualism & -0.0750 & 0.0829 & 0.189 & $0.256^{* *}$ & $-0.221^{*}$ & 0.0810 & $0.231^{*}$ & -0.0587 & $0.294^{* *}$ & 1 \\
\hline
\end{tabular}

All variables are defined in Table 1. ***, and *** denote significance at 10\%, 5\% and $1 \%$ levels respectively.

\section{Collinearity Diagnostics}

\begin{tabular}{llcc}
\hline Variable & VIF & SQRT-VIF & Tolerance \\
\hline Size & 2.68 & 1.64 & 0.3730 \\
\hline EQ_TA & 1.93 & 1.39 & 0.5189 \\
\hline ROE & 1.51 & 1.23 & 0.6270 \\
\hline Growth_TA & 1.17 & 1.08 & 0.4811 \\
\hline Deposit_TA & 1.67 & 0.3380 & 0.8547 \\
\hline Opacity & 1.51 & 1.29 & 0.5985 \\
\hline ZScore & 1.46 & 1.23 & 0.6642 \\
\hline D_Controlling & 1.09 & 1.21 & 0.6868 \\
\hline RADI & 1.21 & 1.04 & 0.3358 \\
\hline Individualism & 1.31 & 1.10 & 0.3132 \\
\hline
\end{tabular}




\section{Appendix C: Robustness test 1 using data of the year 2014}

Table C1: Is the national supportive policy effective to promote employee share ownership programs?

This table reports the results of the regression estimates models where the dependent variable is the dummy variable D_ESOP. Columns 1 and 2 report 1st and 2 nd stage ivprobit regression estimates obtained when the Country index is instrumented with the number of labor-support-parties presented in parliament. Columns 3 and 4 report 1 st and 2nd stage ivprobit regression estimates obtained when the Legal index is instrumented with the number of labor-support-parties presented in parliament. Columns 5 and 6 report 1 st and 2nd stage ivprobit regression estimates obtained when the Fiscal index is instrumented with the number of labor-support-parties presented in parliament. For main results: the corresponding t-statistics are reported in parentheses. For weak instrument robust tests: p-values in parentheses. With *, $* *$, and $* * *$ denoting significance at $10 \%, 5 \%$ and $1 \%$ levels.

\begin{tabular}{|c|c|c|c|c|c|c|}
\hline & $\begin{array}{c}\text { (1) } \\
\text { ivprobit } \\
\text { 1st Stage }\end{array}$ & $\begin{array}{c}(2) \\
\text { ivprobit } \\
\text { 2nd Stage }\end{array}$ & $\begin{array}{c}(3) \\
\text { ivprobit } \\
\text { 1st Stage }\end{array}$ & $\begin{array}{c}(4) \\
\text { ivprobit } \\
\text { 2nd Stage }\end{array}$ & $\begin{array}{c}(5) \\
\text { ivprobit } \\
\text { 1st Stage }\end{array}$ & $\begin{array}{c}(6) \\
\text { ivprobit } \\
\text { 2nd Stage }\end{array}$ \\
\hline IV_Country index & & $\begin{array}{c}0.571^{* * * *} \\
(2.66)\end{array}$ & & & & \\
\hline IV_Legal index & & & & $\begin{array}{c}2.182^{* *} \\
(2.56)\end{array}$ & & \\
\hline IV_Fisclal index & & & & & & $\begin{array}{c}0.762^{* * *} \\
(2.64)\end{array}$ \\
\hline Labor-support-parties & $\begin{array}{c}0.439^{* * * *} \\
(4.34)\end{array}$ & & $\begin{array}{c}0.117^{* * * *} \\
(3.20)\end{array}$ & & $\begin{array}{c}0.322^{* * *} \\
(4.70)\end{array}$ & \\
\hline Size_lag(1) & $\begin{array}{l}0.204^{*} \\
(1.88)\end{array}$ & $\begin{array}{c}0.0580 \\
(0.47)\end{array}$ & $\begin{array}{c}0.0485 \\
(1.23)\end{array}$ & $\begin{array}{c}0.0398 \\
(0.31)\end{array}$ & $\begin{array}{l}0.156^{* * *} \\
(2.12)\end{array}$ & $\begin{array}{c}0.0643 \\
(0.52)\end{array}$ \\
\hline Equity_TA_lag(1) & $\begin{array}{l}5.973 \\
(1.39)\end{array}$ & $\begin{array}{l}-3.354 \\
(-0.79)\end{array}$ & $\begin{array}{l}2.634^{*} \\
(1.70)\end{array}$ & $\begin{array}{l}-6.469 \\
(-1.29)\end{array}$ & $\begin{array}{l}3.339 \\
(1.15)\end{array}$ & $\begin{array}{l}-2.069 \\
(-0.51)\end{array}$ \\
\hline ROE_lag(1) & $\begin{array}{l}0.261 \\
(0.23)\end{array}$ & $\begin{array}{l}0.337 \\
(0.31)\end{array}$ & $\begin{array}{c}0.0853 \\
(0.21)\end{array}$ & $\begin{array}{l}0.393 \\
(0.35)\end{array}$ & $\begin{array}{l}0.176 \\
(0.23)\end{array}$ & $\begin{array}{l}0.302 \\
(0.28)\end{array}$ \\
\hline Growth_TA_lag(1) & $\begin{array}{l}-0.808 \\
(-0.62)\end{array}$ & $\begin{array}{l}1.239 \\
(0.92)\end{array}$ & $\begin{array}{l}-0.388 \\
(-0.82)\end{array}$ & $\begin{array}{l}1.572 \\
(1.09)\end{array}$ & $\begin{array}{l}-0.420 \\
(-0.48)\end{array}$ & $\begin{array}{l}1.042 \\
(0.79)\end{array}$ \\
\hline Deposit_TA_lag(1) & $\begin{array}{l}0.501 \\
(0.40)\end{array}$ & $\begin{array}{l}-2.560^{*} \\
(-1.65)\end{array}$ & $\begin{array}{c}-0.0237 \\
(-0.05)\end{array}$ & $\begin{array}{l}-2.492 \\
(-1.51)\end{array}$ & $\begin{array}{l}0.524 \\
(0.61)\end{array}$ & $\begin{array}{l}-2.421 \\
(-1.63)\end{array}$ \\
\hline Opacity_lag(1) & $\begin{array}{c}-0.252^{* * *} \\
(-2.07)\end{array}$ & $\begin{array}{c}0.0227 \\
(0.18)\end{array}$ & $\begin{array}{c}-0.132^{* * * *} \\
(-3.00)\end{array}$ & $\begin{array}{l}0.173 \\
(1.07)\end{array}$ & $\begin{array}{l}-0.120 \\
(-1.45)\end{array}$ & $\begin{array}{c}-0.0311 \\
(-0.26)\end{array}$ \\
\hline Z-Score_lag(1) & $\begin{array}{l}0.204 \\
(1.52)\end{array}$ & $\begin{array}{c}0.0894 \\
(0.73)\end{array}$ & $\begin{array}{r}0.0838^{*} \\
(1.72)\end{array}$ & $\begin{array}{c}0.0141 \\
(0.10)\end{array}$ & $\begin{array}{l}0.120 \\
(1.32)\end{array}$ & $\begin{array}{l}0.111 \\
(0.92)\end{array}$ \\
\hline D_Controlling & $\begin{array}{l}0.535 \\
(1.49)\end{array}$ & $\begin{array}{l}-0.374 \\
(-0.99)\end{array}$ & $\begin{array}{l}0.119 \\
(0.91)\end{array}$ & $\begin{array}{l}-0.363 \\
(-0.94)\end{array}$ & $\begin{array}{l}0.416^{*} \\
(1.72)\end{array}$ & $\begin{array}{l}-0.375 \\
(-1.01)\end{array}$ \\
\hline RADI & $\begin{array}{c}0.728^{* * * *} \\
(3.30)\end{array}$ & $\begin{array}{l}-0.476^{* *} \\
(-2.39)\end{array}$ & $\begin{array}{l}0.127 \\
(1.59)\end{array}$ & $\begin{array}{l}-0.361^{*} \\
(-1.92)\end{array}$ & $\begin{array}{c}0.601^{* * * *} \\
(4.03)\end{array}$ & $\begin{array}{c}-0.515^{* *} \\
(-2.48)\end{array}$ \\
\hline Individualism & $\begin{array}{c}0.00714 \\
(0.47) \\
\end{array}$ & $\begin{array}{l}0.0167 \\
(1.08) \\
\end{array}$ & $\begin{array}{c}0.0123^{* *} \\
(2.21) \\
\end{array}$ & $\begin{array}{c}-0.00967 \\
(-0.46) \\
\end{array}$ & $\begin{array}{c}-0.00511 \\
(-0.49) \\
\end{array}$ & $\begin{array}{c}0.0267^{*} \\
(1.82) \\
\end{array}$ \\
\hline Observations & 102 & 102 & 102 & 102 & 102 & 102 \\
\hline \multicolumn{7}{|c|}{ Weak instrument robust tests and confidence sets for ivprobit } \\
\hline $\begin{array}{l}\text { Anderson-Rubin test } \\
\text { (p-value) }\end{array}$ & & $\begin{array}{c}6.06 \\
(0.0138)\end{array}$ & & $\begin{array}{c}6.25 \\
(0.0124)\end{array}$ & & $\begin{array}{c}6.01 \\
(0.0142)\end{array}$ \\
\hline $\begin{array}{l}\text { Wald test } \\
\qquad(\mathrm{p} \text {-value) }\end{array}$ & & $\begin{array}{c}7.10 \\
(0.0077)\end{array}$ & & $\begin{array}{c}6.58 \\
(0.0103)\end{array}$ & & $\begin{array}{c}6.95 \\
(0.0084)\end{array}$ \\
\hline
\end{tabular}


Table C2: Ownership structure and effectiveness of national supportive measures

This table reports regression estimates of the 2nd stage of the ivprobit models where the dependent variable is $D \_E S O P$. Colum 1, 2, 3 report the results when the Country index, the Legal index and the Fiscal index is instrumented with the number of labor-support-parties, respectively.

\begin{tabular}{|c|c|c|c|}
\hline Dependent variable: & $\begin{array}{c}\text { D_ESOP } \\
\text { (1) } \\
\text { ivprobit } \\
\text { 2nd Stage }\end{array}$ & $\begin{array}{c}\text { D_ESOP } \\
\text { (2) } \\
\text { ivprobit } \\
\text { 2nd Stage }\end{array}$ & $\begin{array}{c}\text { D_ESOP } \\
\text { (3) } \\
\text { ivprobit } \\
\text { 2nd Stage }\end{array}$ \\
\hline $\begin{array}{l}\text { Instrumented Country index (b1) } \\
\text { Instrumented Country index } * \text { D_Controlling (b2) }\end{array}$ & $\begin{array}{l}0.464 * * * \\
(4.62) \\
-0.154 \\
(-0.69)\end{array}$ & & \\
\hline $\begin{array}{l}\text { Instrumented Legal index (b1) } \\
\text { Instrumented Legal index } * \text { D_Controlling (b2) }\end{array}$ & & $\begin{array}{l}1.210 * * * \\
(4.04) \\
0.00451 \\
(0.01)\end{array}$ & \\
\hline $\begin{array}{l}\text { Instrumented Fiscal index (b1) } \\
\text { Instrumented Fiscal index * D_Controlling (b2) }\end{array}$ & & & $\begin{array}{c}0.656 * * * \\
(4.57) \\
-0.298 \\
(-0.96)\end{array}$ \\
\hline D_Controlling & $\begin{array}{l}0.253 \\
(0.28)\end{array}$ & $\begin{array}{l}-0.290 \\
(-0.20)\end{array}$ & $\begin{array}{l}0.227 \\
(0.34)\end{array}$ \\
\hline Size_lag(1) & $\begin{array}{l}0.113 \\
(1.08)\end{array}$ & $\begin{array}{c}0.125 \\
(1.18)\end{array}$ & $\begin{array}{l}0.120 \\
(1.16)\end{array}$ \\
\hline Equity_TA_lag(1) & $\begin{array}{l}-1.475 \\
(-0.39)\end{array}$ & $\begin{array}{l}-2.519 \\
(-0.58)\end{array}$ & $\begin{array}{l}-0.559 \\
(-0.16)\end{array}$ \\
\hline $\mathrm{ROE}_{-} \operatorname{lag}(1)$ & $\begin{array}{l}0.156 \\
(0.15)\end{array}$ & $\begin{array}{l}0.135 \\
(0.13)\end{array}$ & $\begin{array}{l}0.122 \\
(0.12)\end{array}$ \\
\hline Growth_TA_lag(1) & $\begin{array}{l}1.212 \\
(0.92)\end{array}$ & $\begin{array}{l}1.522 \\
(1.13)\end{array}$ & $\begin{array}{l}1.101 \\
(0.86)\end{array}$ \\
\hline Deposit_TA_lag(1) & $\begin{array}{l}-2.237 \\
(-1.49)\end{array}$ & $\begin{array}{l}-1.861 \\
(-1.14)\end{array}$ & $\begin{array}{l}-2.054 \\
(-1.45)\end{array}$ \\
\hline Opacity_lag(1) & $\begin{array}{l}-0.0413 \\
(-0.33)\end{array}$ & $\begin{array}{c}0.0793 \\
(0.59)\end{array}$ & $\begin{array}{c}-0.0832 \\
(-0.69)\end{array}$ \\
\hline Z-Score_lag(1) & $\begin{array}{l}0.122 \\
(0.99)\end{array}$ & $\begin{array}{c}0.0276 \\
(0.21)\end{array}$ & $\begin{array}{l}0.137 \\
(1.14)\end{array}$ \\
\hline RADI & $\begin{array}{c}-0.385^{* *} \\
(-2.10)\end{array}$ & $\begin{array}{l}-0.732^{*} \\
(-1.92)\end{array}$ & $\begin{array}{c}-0.398^{* *} \\
(-2.13)\end{array}$ \\
\hline Individualism & $\begin{array}{c}0.0247 \\
(1.64)\end{array}$ & $\begin{array}{c}0.0109 \\
(0.62)\end{array}$ & $\begin{array}{c}0.0327^{* *} \\
(2.19)\end{array}$ \\
\hline Observation & 102 & 102 & 102 \\
\hline \multicolumn{4}{|l|}{ Wald test } \\
\hline $\mathrm{b} 1+\mathrm{b} 2=0$ & $\begin{array}{c}0.309 \\
(1.935)\end{array}$ & $\begin{array}{c}1.215 \\
(2.193)\end{array}$ & $\begin{array}{c}0.357 \\
(1.394)\end{array}$ \\
\hline
\end{tabular}

The t-statistics are in parentheses, with *,**, and *** denoting significance at $10 \%, 5 \%$ and $1 \%$ levels. 
Table C3: Ownership structure, degrees of opacity, and effectiveness of national supportive measures

This table reports regression estimates of the 2 nd stage of the ivprobit models where the dependent variable is D_ESOP. Colum 1, 2, 3 report the results when Country index, Legal index and Fiscal index is instrumented with the number of labor-support-parties, respectively.

\begin{tabular}{|c|c|c|c|}
\hline Dependent variable: & $\begin{array}{c}\text { D_ESOP } \\
(1) \\
\text { ivprobit } \\
\text { 2nd Stage }\end{array}$ & $\begin{array}{c}D \_E S O P \\
(2) \\
\text { ivprobit } \\
\text { 2nd Stage }\end{array}$ & $\begin{array}{c}D \_E S O P \\
(3) \\
\text { ivprobit } \\
\text { 2nd Stage }\end{array}$ \\
\hline IV_Country index (b1) & $\begin{array}{l}1.629 * * * \\
(3.14)\end{array}$ & & \\
\hline IV_Country index * D_Controlling(b2) & $\begin{array}{l}-1.073^{* *} \\
(-2.47)\end{array}$ & & \\
\hline IV_Country index * D_Opacity (b3) & $\begin{array}{l}-0.903^{*} \\
(-1.96)\end{array}$ & & \\
\hline IV_Country index * D_Controlling* D_Opacity (b4) & $\begin{array}{c}0.578^{* * *} \\
(2.26)\end{array}$ & & \\
\hline IV_Legal index (b1) & & $\begin{array}{l}3.412 * * * \\
(2.65)\end{array}$ & \\
\hline IV_Legal index * D_Controlling(b2) & & $\begin{array}{l}-1.584 \\
(-1.45)\end{array}$ & \\
\hline IV_Legal index * D_Opacity (b3) & & $\begin{array}{l}-1.352 \\
(-1.26)\end{array}$ & \\
\hline IV_Legal index * D_Controlling* D_Opacity (b4) & & $0.958^{* *}$ & \\
\hline IV_Fiscal index (b1) & & & $\begin{array}{l}2.737 * * * \\
(2.86)\end{array}$ \\
\hline IV_Fiscal index $*$ D_Controlling(b2) & & & $\begin{array}{c}-2.021^{* * *} \\
(-2.44)\end{array}$ \\
\hline IV_Fiscal index * D_Opacity (b3) & & & $\begin{array}{l}-1.735^{*} \\
(-1.93)\end{array}$ \\
\hline IV_Fiscal index * D_Controlling* D_Opacity (b4) & & & $1.295^{* *}$ \\
\hline D_Opacity & $\begin{array}{r}1.982 \\
(1.56)\end{array}$ & $\begin{array}{l}1.832 \\
(1.05)\end{array}$ & $\begin{array}{l}1.438 \\
(1.51)\end{array}$ \\
\hline D_Controlling & $\begin{array}{l}2.081^{*} \\
(1.79)\end{array}$ & $\begin{array}{l}1.597 \\
(0.87) \\
\end{array}$ & $\begin{array}{l}1.555^{*} \\
(1.91)\end{array}$ \\
\hline Control variables & Yes & Yes & Yes \\
\hline Observation & 102 & 102 & 102 \\
\hline \multicolumn{4}{|l|}{ Wald tests } \\
\hline $\mathrm{b} 1+\mathrm{b} 2=0$ & $\begin{array}{c}0.556^{* *} \\
(4.376)\end{array}$ & $\begin{array}{l}1.828 * * \\
(5.656)\end{array}$ & $\begin{array}{l}0.716^{*} \\
(3.428)\end{array}$ \\
\hline$b 1+b 3=0$ & $\begin{array}{c}0.726 * * \\
(5.036)\end{array}$ & $\begin{array}{l}2.061^{*} \\
(3.341)\end{array}$ & $\begin{array}{l}1.002 * * \\
(5.461)\end{array}$ \\
\hline$b 1+b 2+b 3+b 4=0$ & $\begin{array}{c}0.231 \\
(0.638)\end{array}$ & $\begin{array}{l}1.435 \\
(2.295)\end{array}$ & $\begin{array}{c}0.277 \\
(0.464)\end{array}$ \\
\hline
\end{tabular}

The t-statistics are in parentheses, with *,**, and *** denoting significance at $10 \%, 5 \%$ and $1 \%$ levels. 
Table C4: Ownership structure, levels of of shareholder protection, and effectiveness of national supportive measures

This table reports regression estimates of the 2 nd stage of the ivprobit models where the dependent variable is D_ESOP. Colum 1, 2, 3 report the results when Country index, Legal index and Fiscal index is instrumented with the number of labor-support-parties, respectively.

\begin{tabular}{|c|c|c|c|}
\hline Dependent variable: & $\begin{array}{c}D \_E S O P \\
(1) \\
\text { ivprobit } \\
\text { 2nd Stage }\end{array}$ & $\begin{array}{c}D \_E S O P \\
(2) \\
\text { ivprobit } \\
\text { 2nd Stage }\end{array}$ & $\begin{array}{c}D \_E S O P \\
(3) \\
\text { ivprobit } \\
\text { 2nd Stage }\end{array}$ \\
\hline IV_Country index (b1) & $\begin{array}{c}1.308^{* * *} * \\
(3.38)\end{array}$ & & \\
\hline IV_Country index *D_Controlling(b2) & $\begin{array}{c}-0.504^{*} \\
(-1.66)\end{array}$ & & \\
\hline IV_Country index *D_RADI (b3) & $\begin{array}{l}-0.396 \\
(-0.85)\end{array}$ & & \\
\hline IV_Country index * D_Controlling* D_RADI (b4) & $\begin{array}{l}-0.234 \\
(-0.98)\end{array}$ & & \\
\hline IV_Legal index (b1) & & $\begin{array}{c}4.054 * * * \\
(2.92)\end{array}$ & \\
\hline IV_Legal index * D_Controlling(b2) & & $\begin{array}{l}-0.931 \\
(-1.00)\end{array}$ & \\
\hline IV_Legal index * D_RADI (b3) & & $\begin{array}{l}-1.202 \\
(-0.99)\end{array}$ & \\
\hline IV_Legal index * D_Controlling* D_RADI (b4) & & $\begin{array}{l}-0.348 \\
(-0.81)\end{array}$ & \\
\hline IV_Fiscal index (b1) & & & $\begin{array}{c}1.712 * * * \\
(3.51)\end{array}$ \\
\hline IV_Fiscal index * D_Controlling(b2) & & & $\begin{array}{l}-0.707^{*} \\
(-1.75)\end{array}$ \\
\hline IV_Fiscal index * D_RADI (b3) & & & $\begin{array}{l}-0.353 \\
(-0.52)\end{array}$ \\
\hline IV_Fiscal index * D_Controlling* D_RADI (b4) & & & $\begin{array}{l}-0.543 \\
(-1.13)\end{array}$ \\
\hline D_RADI & $\begin{array}{c}3.425 * * \\
(2.22)\end{array}$ & $\begin{array}{c}3.668^{*} \\
(1.74)\end{array}$ & $\begin{array}{c}2.815^{* * * *} \\
(2.60)\end{array}$ \\
\hline D_Controlling & $\begin{array}{l}1.567 \\
(1.35) \\
\end{array}$ & $\begin{array}{r}1.467 \\
(0.88) \\
\end{array}$ & $\begin{array}{r}1.023 \\
(1.28) \\
\end{array}$ \\
\hline Control variables & Yes & Yes & Yes \\
\hline Observation & 102 & 102 & 102 \\
\hline \multicolumn{4}{|l|}{ Wald tests } \\
\hline $\mathrm{b} 1+\mathrm{b} 2=0$ & $\begin{array}{c}0.803^{* *} \\
(4.985)\end{array}$ & $\begin{array}{l}3.124 * * \\
(5.905)\end{array}$ & $\begin{array}{c}1.005^{* *} \\
(4.839)\end{array}$ \\
\hline$b 1+b 3=0$ & $\begin{array}{c}0.912 * * \\
(5.054)\end{array}$ & $\begin{array}{c}2.852 * * \\
(6.603)\end{array}$ & $\begin{array}{c}1.359 * * \\
(4.706)\end{array}$ \\
\hline$b 1+b 2+b 3+b 4=0$ & $\begin{array}{c}0.173 \\
(0.589)\end{array}$ & $\begin{array}{c}1.573 \\
(0.046)\end{array}$ & $\begin{array}{c}0.109 \\
(0.116)\end{array}$ \\
\hline
\end{tabular}

The t-statistics are in parentheses, with *, $* *$, and $* * *$ denoting significance at $10 \%, 5 \%$ and $1 \%$ levels. 


\section{Appendix D: Robustness test 2 using ownership threshold at $10 \%$ of outstanding shares.}

Table D1: Does the national supportive policy is effective to promote employee share ownership programs?

This table reports regression estimates models where the dependent variable is the dummy variable D_ESOP. Columns 1 and 2 report 1st and 2nd stage ivprobit regression estimates obtained when the Country index is instrumented with the number of labor-support-parties. Columns 3 and 4 report 1 st and 2nd stage ivprobit regression estimates obtained when the Legal index is instrumented with the number of labor-support-parties. Columns 5 and 6 report 1 st and 2 nd stage ivprobit regression estimates obtained when the Fiscal index is instrumented with the number of labor-support-parties. For main results: the corresponding t-statistics are reported in parentheses. For weak instrument robust tests: p-values in parentheses. With $*, * *$, and $* * *$ denoting significance at $10 \%, 5 \%$ and $1 \%$ levels.

\begin{tabular}{|c|c|c|c|c|c|c|}
\hline & $\begin{array}{c}\text { (1) } \\
\text { ivprobit } \\
\text { 1st Stage }\end{array}$ & $\begin{array}{c}(2) \\
\text { ivprobit } \\
\text { 2nd Stage }\end{array}$ & $\begin{array}{c}(3) \\
\text { ivprobit } \\
\text { 1st Stage }\end{array}$ & $\begin{array}{c}\text { (4) } \\
\text { ivprobit } \\
\text { 2nd Stage }\end{array}$ & $\begin{array}{c}(5) \\
\text { ivprobit } \\
\text { 1st Stage }\end{array}$ & $\begin{array}{c}(6) \\
\text { ivprobit } \\
\text { 2nd Stage }\end{array}$ \\
\hline IV_Country index & & $\begin{array}{c}0.604 * * \\
(2.54)\end{array}$ & & & & \\
\hline IV_Legal index & & & & $\begin{array}{c}2.364 * * \\
(2.41)\end{array}$ & & \\
\hline IV_Fisclal index & & & & & & $\begin{array}{c}0.798 * * \\
(2.52)\end{array}$ \\
\hline Labor-support-parties & $\begin{array}{c}0.407 * * * \\
(4.08)\end{array}$ & & $\begin{array}{c}0.106 * * * \\
(2.94)\end{array}$ & & $\begin{array}{c}0.300 * * * \\
(4.44)\end{array}$ & \\
\hline Size_lag(1) & $\begin{array}{c}0.293^{* * * *} \\
(2.77)\end{array}$ & $\begin{array}{c}-0.00311 \\
(-0.02)\end{array}$ & $\begin{array}{c}0.0790^{* *} \\
(2.06)\end{array}$ & $\begin{array}{l}-0.0437 \\
(-0.29)\end{array}$ & $\begin{array}{c}0.214^{* * * *} \\
(2.99)\end{array}$ & $\begin{array}{c}0.0155 \\
(0.11)\end{array}$ \\
\hline Equity_TA_lag(1) & $\begin{array}{l}10.52^{* *} \\
(2.40)\end{array}$ & $\begin{array}{l}-4.945 \\
(-0.95)\end{array}$ & $\begin{array}{c}4.156^{* * *} \\
(2.62)\end{array}$ & $\begin{array}{l}-9.264 \\
(-1.40)\end{array}$ & $\begin{array}{c}6.360^{* * *} \\
(2.14)\end{array}$ & $\begin{array}{l}-3.197 \\
(-0.66)\end{array}$ \\
\hline ROE_lag(1) & $\begin{array}{l}-0.322 \\
(-0.25)\end{array}$ & $\begin{array}{l}1.196 \\
(0.75)\end{array}$ & $\begin{array}{c}0.0611 \\
(0.13)\end{array}$ & $\begin{array}{l}0.885 \\
(0.55)\end{array}$ & $\begin{array}{l}-0.383 \\
(-0.44)\end{array}$ & $\begin{array}{l}1.236 \\
(0.78)\end{array}$ \\
\hline Growth_TA_lag(1) & $\begin{array}{l}1.534 \\
(1.32)\end{array}$ & $\begin{array}{l}-0.344 \\
(-0.28)\end{array}$ & $\begin{array}{l}0.414 \\
(0.98)\end{array}$ & $\begin{array}{l}-0.406 \\
(-0.31)\end{array}$ & $\begin{array}{l}1.119 \\
(1.42)\end{array}$ & $\begin{array}{l}-0.295 \\
(-0.24)\end{array}$ \\
\hline Deposit_TA_lag(1) & $\begin{array}{l}1.070 \\
(0.87)\end{array}$ & $\begin{array}{l}-2.627^{*} \\
(-1.71)\end{array}$ & $\begin{array}{l}0.219 \\
(0.49)\end{array}$ & $\begin{array}{l}-2.742^{*} \\
(-1.70)\end{array}$ & $\begin{array}{l}0.852 \\
(1.02)\end{array}$ & $\begin{array}{l}-2.371 \\
(-1.62)\end{array}$ \\
\hline Opacity_lag(1) & $\begin{array}{l}-0.282^{* * *} \\
(-2.23)\end{array}$ & $\begin{array}{l}0.0129 \\
(0.09)\end{array}$ & $\begin{array}{c}-0.149^{* * *} \\
(-3.25)\end{array}$ & $\begin{array}{l}0.208 \\
(1.05)\end{array}$ & $\begin{array}{l}-0.133 \\
(-1.55)\end{array}$ & $\begin{array}{c}-0.0540 \\
(-0.40)\end{array}$ \\
\hline Z-Score_lag(1) & $\begin{array}{l}0.173 \\
(1.26)\end{array}$ & $\begin{array}{l}0.0715 \\
(0.54)\end{array}$ & $\begin{array}{c}0.0630 \\
(1.27)\end{array}$ & $\begin{array}{c}0.0156 \\
(0.11)\end{array}$ & $\begin{array}{l}0.110 \\
(1.18)\end{array}$ & $\begin{array}{c}0.0897 \\
(0.69)\end{array}$ \\
\hline D_Controlling_10 & $\begin{array}{c}0.0624 \\
(0.16)\end{array}$ & $\begin{array}{l}-0.885^{*} \\
(-1.81)\end{array}$ & $\begin{array}{c}-0.0439 \\
(-0.31)\end{array}$ & $\begin{array}{l}-0.723 \\
(-1.47)\end{array}$ & $\begin{array}{l}0.106 \\
(0.41)\end{array}$ & $\begin{array}{l}-0.914^{*} \\
(-1.92)\end{array}$ \\
\hline RADI & $\begin{array}{c}0.600^{* * * *} \\
(2.76)\end{array}$ & $\begin{array}{c}-0.505^{* * *} \\
(-2.43)\end{array}$ & $\begin{array}{c}0.0888 \\
(1.13)\end{array}$ & $\begin{array}{l}-0.365^{*} \\
(-1.82)\end{array}$ & $\begin{array}{c}0.512^{* * *} \\
(3.47)\end{array}$ & $\begin{array}{c}-0.547^{* * *} \\
(-2.55)\end{array}$ \\
\hline Individualism & $\begin{array}{c}0.00842 \\
(0.55) \\
\end{array}$ & $\begin{array}{c}0.0153 \\
(0.97) \\
\end{array}$ & $\begin{array}{c}0.0131^{* *} \\
(2.36) \\
\end{array}$ & $\begin{array}{r}-0.0147 \\
(-0.64) \\
\end{array}$ & $\begin{array}{c}-0.00464 \\
(-0.45) \\
\end{array}$ & $\begin{array}{c}0.0264^{*} \\
(1.77) \\
\end{array}$ \\
\hline Observations & 103 & 103 & 103 & 103 & 103 & 103 \\
\hline \multicolumn{7}{|c|}{ Weak instrument robust tests and confidence sets for ivprobit } \\
\hline $\begin{array}{l}\text { Anderson-Rubin test } \\
\text { (p-value) }\end{array}$ & & $\begin{array}{c}5.60 \\
(0.0180)\end{array}$ & & $\begin{array}{c}5.84 \\
(0.0157)\end{array}$ & & $\begin{array}{c}5.52 \\
(0.0188)\end{array}$ \\
\hline $\begin{array}{l}\text { Wald test } \\
\qquad(\mathrm{p} \text {-value) }\end{array}$ & & $\begin{array}{c}6.46 \\
(0.0110) \\
\end{array}$ & & $\begin{array}{c}5.83 \\
(0.0157)\end{array}$ & & $\begin{array}{c}6.33 \\
(0.0119) \\
\end{array}$ \\
\hline
\end{tabular}


Table D2: Ownership structure and effectiveness of national supportive measures

This table reports regression estimates of the 2nd stage of the ivprobit models where the dependent variable is $D \_E S O P$. Colum 1, 2, 3 report the results when the Country index, the Legal index and the Fiscal index is instrumented with the number of labor-support-parties, respectively.

\begin{tabular}{|c|c|c|c|}
\hline Dependent variable: & $\begin{array}{c}\text { D_ESOP } \\
\text { (1) } \\
\text { ivprobit } \\
\text { 2nd Stage }\end{array}$ & $\begin{array}{c}\text { D_ESOP } \\
\text { (2) } \\
\text { ivprobit } \\
\text { 2nd Stage }\end{array}$ & $\begin{array}{c}\text { D_ESOP } \\
\text { (3) } \\
\text { ivprobit } \\
\text { 2nd Stage }\end{array}$ \\
\hline $\begin{array}{l}\text { Instrumented Country index (b1) } \\
\text { Instrumented Country index * D_Controlling_10 (b2) }\end{array}$ & $\begin{array}{l}0.468 * * * \\
(4.53) \\
-0.116 \\
(-0.52)\end{array}$ & & \\
\hline $\begin{array}{l}\text { Instrumented Legal index (b1) } \\
\text { Instrumented Legal index * D_Controlling_10 (b2) }\end{array}$ & & $\begin{array}{l}1.167 * * * \\
(3.90) \\
0.213 \\
(0.24)\end{array}$ & \\
\hline $\begin{array}{l}\text { Instrumented Fiscal index (b1) } \\
\text { Instrumented Fiscal index * D_Controlling_10 (b2) }\end{array}$ & & & $\begin{array}{l}0.662 * * * \\
(4.46) \\
-0.223 \\
(-0.73)\end{array}$ \\
\hline D_Controlling_10 & $\begin{array}{l}-0.484 \\
(-0.54)\end{array}$ & $\begin{array}{l}-1.121 \\
(-0.67)\end{array}$ & $\begin{array}{l}-0.543 \\
(-0.80)\end{array}$ \\
\hline Size & $\begin{array}{c}0.0864 \\
(0.72)\end{array}$ & $\begin{array}{c}0.0625 \\
(0.48)\end{array}$ & $\begin{array}{l}0.105 \\
(0.90)\end{array}$ \\
\hline Equity over total assets & $\begin{array}{l}-1.525 \\
(-0.33)\end{array}$ & $\begin{array}{l}-3.931 \\
(-0.65)\end{array}$ & $\begin{array}{l}-0.195 \\
(-0.04)\end{array}$ \\
\hline ROE & $\begin{array}{l}1.131 \\
(0.73)\end{array}$ & $\begin{array}{l}0.587 \\
(0.44)\end{array}$ & $\begin{array}{r}1.136 \\
(0.73)\end{array}$ \\
\hline Growth of total assets & $\begin{array}{c}-0.0466 \\
(-0.04)\end{array}$ & $\begin{array}{l}0.136 \\
(0.11)\end{array}$ & $\begin{array}{c}-0.00213 \\
(-0.00)\end{array}$ \\
\hline Deposit over total assets & $\begin{array}{l}-2.133 \\
(-1.41)\end{array}$ & $\begin{array}{l}-1.926 \\
(-1.18)\end{array}$ & $\begin{array}{l}-1.852 \\
(-1.31)\end{array}$ \\
\hline Opacity & $\begin{array}{c}-0.0640 \\
(-0.45)\end{array}$ & $\begin{array}{c}0.0960 \\
(0.59)\end{array}$ & $\begin{array}{l}-0.111 \\
(-0.83)\end{array}$ \\
\hline Z-Score & $\begin{array}{l}0.0903 \\
(0.69)\end{array}$ & $\begin{array}{c}0.0166 \\
(0.12)\end{array}$ & $\begin{array}{l}0.105 \\
(0.81)\end{array}$ \\
\hline RADI & $\begin{array}{c}-0.424^{* *} \\
(-2.16)\end{array}$ & $\begin{array}{l}-0.741^{*} \\
(-1.80)\end{array}$ & $\begin{array}{c}-0.440^{* *} \\
(-2.19)\end{array}$ \\
\hline Individualism & $\begin{array}{l}0.0236 \\
(1.48)\end{array}$ & $\begin{array}{c}0.00499 \\
(0.22)\end{array}$ & $\begin{array}{c}0.0324^{* *} \\
(2.08)\end{array}$ \\
\hline $\begin{array}{l}\text { Observation } \\
\text { Wald test }\end{array}$ & 103 & 103 & 103 \\
\hline $\mathrm{b} 1+\mathrm{b} 2=0$ & $\begin{array}{c}0.352 \\
(2.440)\end{array}$ & $\begin{array}{l}1.380 \\
(2.079)\end{array}$ & $\begin{array}{c}0.439 \\
(2.179)\end{array}$ \\
\hline
\end{tabular}

The t-statistics are in parentheses, with *,**, and *** denoting significance at $10 \%, 5 \%$ and $1 \%$ levels. 
Table D3: Ownership structure, degrees of opacity, and effectiveness of national supportive measures

This table reports regression estimates of the 2 nd stage of the ivprobit models where the dependent variable is D_ESOP. Colum 1, 2, 3 report the results when Country index, Legal index and Fiscal index is instrumented with the number of labor-support-parties, respectively.

\begin{tabular}{|c|c|c|c|}
\hline Dependent variable: & $\begin{array}{c}D \_E S O P \\
(1) \\
\text { ivprobit } \\
\text { 2nd Stage }\end{array}$ & $\begin{array}{c}D \_E S O P \\
(2) \\
\text { ivprobit } \\
\text { 2nd Stage }\end{array}$ & $\begin{array}{c}D \_E S O P \\
(3) \\
\text { ivprobit } \\
\text { 2nd Stage }\end{array}$ \\
\hline IV_Country index (b1) & $\begin{array}{c}2.435 * * * \\
(3.04)\end{array}$ & & \\
\hline IV_Country index *D_Controlling_10 (b2) & $\begin{array}{c}-1.723^{* *} \\
(-2.44)\end{array}$ & & \\
\hline IV_Country index *D_Opacity (b3) & $\begin{array}{l}-0.992^{*} \\
(-1.77)\end{array}$ & & \\
\hline IV_Country index $*$ D_Controlling_10 $*$ D_Opacity (b4) & $\begin{array}{c}0.713^{*} \\
(1.77)\end{array}$ & & \\
\hline IV_Legal index (b1) & & $\begin{array}{l}6.804 * * \\
(2.43)\end{array}$ & \\
\hline IV_Legal index * D_Controlling_10 (b2) & & $\begin{array}{c}-4.549^{*} \\
(-1.75)\end{array}$ & \\
\hline IV_Legal index * D_Opacity (b3) & & $\begin{array}{l}-1.650 \\
(-1.45)\end{array}$ & \\
\hline IV_Legal index * D_Controlling * D_Opacity (b4) & & $1.144^{*}$ & \\
\hline IV_Fiscal index (b1) & & & $\begin{array}{c}4.085 * * * \\
(2.83)\end{array}$ \\
\hline IV_Fiscal index * D_Controlling_10 (b2) & & & $\begin{array}{c}-3.096^{* *} \\
(-2.38)\end{array}$ \\
\hline IV_Fiscal index * D_Opacity (b3) & & & $\begin{array}{l}-2.287^{*} \\
(-1.84)\end{array}$ \\
\hline IV_Fiscal index $*$ D_Controlling_10 $*$ D_Opacity (b4) & & & $1.868^{*}$ \\
\hline D_Opacity & $\begin{array}{l}1.773 \\
(1.48)\end{array}$ & $\begin{array}{l}2.031 \\
(1.24)\end{array}$ & $\begin{array}{l}1.344 \\
(1.49)\end{array}$ \\
\hline D_Controlling_10 & $\begin{array}{l}3.099^{*} \\
(1.93)\end{array}$ & $\begin{array}{l}5.802 \\
(1.44) \\
\end{array}$ & $\begin{array}{l}1.711^{*} \\
(1.78)\end{array}$ \\
\hline Control variables & Yes & Yes & Yes \\
\hline Observation & 103 & 103 & 103 \\
\hline \multicolumn{4}{|l|}{ Wald tests } \\
\hline $\mathrm{b} 1+\mathrm{b} 2=0$ & $\begin{array}{c}0.713 * * * \\
(6.840)\end{array}$ & $\begin{array}{c}2.255^{* * *} * \\
(7.946)\end{array}$ & $\begin{array}{c}0.989 * * \\
(6.064)\end{array}$ \\
\hline $\mathrm{b} 1+\mathrm{b} 3=0$ & $\begin{array}{l}1.443^{* *} \\
(6.629)\end{array}$ & $\begin{array}{c}5.153^{* *} \\
(4.097)\end{array}$ & $\begin{array}{c}1.798 * * * \\
(6.915)\end{array}$ \\
\hline$b 1+b 2+b 3+b 4=0$ & $\begin{array}{c}0.434 \\
(2.557)\end{array}$ & $\begin{array}{c}1.749 \\
(0.051)\end{array}$ & $\begin{array}{c}0.570 \\
(2.304)\end{array}$ \\
\hline
\end{tabular}

The t-statistics are in parentheses, with *,**, and *** denoting significance at $10 \%, 5 \%$ and $1 \%$ levels. 
Table D4: Ownership structure, levels of of shareholder protection, and effectiveness of national supportive measures

This table reports regression estimates of the 2nd stage of the ivprobit models where the dependent variable is D_ESOP. Colum 1, 2, 3 report the results when Country index, Legal index and Fiscal index is instrumented with the number of labor-support-parties, respectively.

\begin{tabular}{|c|c|c|c|}
\hline Dependent variable: & $\begin{array}{c}D \_E S O P \\
(1) \\
\text { ivprobit } \\
\text { 2nd Stage }\end{array}$ & $\begin{array}{c}D \_E S O P \\
\text { (2) } \\
\text { ivprobit } \\
\text { 2nd Stage }\end{array}$ & $\begin{array}{c}D \_E S O P \\
(3) \\
\text { ivprobit } \\
\text { 2nd } \\
\text { Stage }\end{array}$ \\
\hline IV_Country index (b1) & $\begin{array}{c}2.903 * * * \\
(3.58)\end{array}$ & & \\
\hline IV_Country index *D_Controlling_10 (b2) & $\begin{array}{c}-1.646^{* *} \\
(-2.36)\end{array}$ & & \\
\hline IV_Country index *D_RADI (b3) & $\begin{array}{l}-0.448 \\
(-0.61)\end{array}$ & & \\
\hline IV_Country index $*$ D_Controlling_10 $*$ D_RADI (b4) & $\begin{array}{l}-0.519 \\
(-1.01)\end{array}$ & & \\
\hline IV_Legal index (b1) & & $\begin{array}{c}11.70^{* * *} \\
(2.38)\end{array}$ & \\
\hline IV_Legal index * D_Controlling_10 (b2) & & $\begin{array}{l}-7.312 \\
(-1.53)\end{array}$ & \\
\hline IV_Legal index * D_RADI (b3) & & $\begin{array}{l}-1.493 \\
(-0.83)\end{array}$ & \\
\hline IV_Legal index $*$ D_Controlling_10 $*$ D_RADI (b4) & & $\begin{array}{l}-0.839 \\
(-0.82)\end{array}$ & \\
\hline IV_Fiscal index (b1) & & & $\begin{array}{c}3.267 * * * * \\
(3.51)\end{array}$ \\
\hline IV_Fiscal index * D_Controlling_10 (b2) & & & $\begin{array}{c}-1.666^{* *} \\
(-2.23)\end{array}$ \\
\hline IV_Fiscal index * D_RADI (b3) & & & $\begin{array}{l}-0.505 \\
(-0.43)\end{array}$ \\
\hline IV_Fiscal index * D_Controlling_10 * D_RADI (b4) & & & $\begin{array}{l}-0.820 \\
(-0.84)\end{array}$ \\
\hline D_RADI & $\begin{array}{c}5.059 * * * \\
(2.87)\end{array}$ & $\begin{array}{c}5.392 * * \\
(2.21)\end{array}$ & $\begin{array}{c}4.007 * * * \\
(3.29)\end{array}$ \\
\hline D_Controlling_10 & $\begin{array}{c}4.586^{* *} \\
(2.01) \\
\end{array}$ & $\begin{array}{l}11.77 \\
(1.44)\end{array}$ & $\begin{array}{l}1.676 \\
(1.63) \\
\end{array}$ \\
\hline Control variables & Yes & Yes & Yes \\
\hline Observation & 103 & 103 & 103 \\
\hline \multicolumn{4}{|l|}{ Wald tests } \\
\hline $\mathrm{b} 1+\mathrm{b} 2=0$ & $\begin{array}{c}1.257 * * * \\
(9.097)\end{array}$ & $\begin{array}{c}4.383 * * * \\
(8.011)\end{array}$ & $\begin{array}{c}1.600 * * * \\
(9.764)\end{array}$ \\
\hline $\mathrm{b} 1+\mathrm{b} 3=0$ & $\begin{array}{c}2.455^{* *} \\
(5.387)\end{array}$ & $\begin{array}{l}10.20^{*} \\
(3.228)\end{array}$ & $\begin{array}{c}2.762 * * \\
(4.644)\end{array}$ \\
\hline$b 1+b 2+b 3+b 4=0$ & $\begin{array}{r}0.290 \\
(1.406) \\
\end{array}$ & $\begin{array}{c}2.052 \\
(0.023)\end{array}$ & $\begin{array}{c}0.276 \\
(0.659) \\
\end{array}$ \\
\hline
\end{tabular}

The t-statistics are in parentheses, with *, $* *$, and ${ }^{* * *}$ denoting significance at $10 \%, 5 \%$ and $1 \%$ levels. 


\section{Appendix E: Robustness test 3 using orthogonalized variables}

Table E1: Does the national supportive policy is effective to promote employee share ownership programs?

This table reports regression estimates models where the dependent variable is the dummy variable $D \_E S O P$. Columns 1 and 2 report 1st and 2nd stage ivprobit regression estimates obtained when the Country index is instrumented with the number of labor-support-parties. Columns 3 and 4 report 1st and 2nd stage ivprobit regression estimates obtained when the Legal index is instrumented with the number of labor-support-parties. Columns 5 and 6 report 1st and 2nd stage ivprobit regression estimates obtained when the Fiscal index is instrumented with the number of labor-support-parties. For main results: the corresponding t-statistics are reported in parentheses. For weak instrument robust tests: p-values in parentheses. With *,**, and *** denoting significance at $10 \%, 5 \%$ and $1 \%$ levels.

\begin{tabular}{|c|c|c|c|c|c|c|}
\hline & $\begin{array}{c}\text { (1) } \\
\text { ivprobit } \\
\text { 1st Stage }\end{array}$ & $\begin{array}{c}(2) \\
\text { ivprobit } \\
\text { 2nd Stage }\end{array}$ & $\begin{array}{c}\text { (3) } \\
\text { ivprobit } \\
\text { 1st Stage }\end{array}$ & $\begin{array}{c}\text { (4) } \\
\text { ivprobit } \\
\text { 2nd Stage }\end{array}$ & $\begin{array}{c}\text { (5) } \\
\text { ivprobit } \\
\text { 1st Stage }\end{array}$ & $\begin{array}{c}\text { (6) } \\
\text { ivprobit } \\
\text { 2nd Stage }\end{array}$ \\
\hline IV_Country index & & $\begin{array}{c}0.579 * * * \\
(2.58)\end{array}$ & & & & \\
\hline IV_Legal index & & & & $\begin{array}{c}2.275^{* *} \\
(2.47)\end{array}$ & & \\
\hline IV_Fisclal index & & & & & & $\begin{array}{c}0.765^{* *} \\
(2.54)\end{array}$ \\
\hline Labor-support-parties & $\begin{array}{c}0.414 * * * \\
(4.19)\end{array}$ & & $\begin{array}{c}0.109 * * * \\
(3.01)\end{array}$ & & $\begin{array}{c}0.305^{* * *} * \\
(4.58)\end{array}$ & \\
\hline Size_lag $(1)$ & $\begin{array}{c}0.208^{* * * *} \\
(3.26)\end{array}$ & $\begin{array}{l}0.137 \\
(1.61)\end{array}$ & $\begin{array}{c}0.0647^{* * * *} \\
(2.78)\end{array}$ & $\begin{array}{c}0.0982 \\
(1.03)\end{array}$ & $\begin{array}{c}0.143^{* * *} \\
(3.33)\end{array}$ & $\begin{array}{l}0.146^{*} \\
(1.76)\end{array}$ \\
\hline oEquity_TA_lag(1) & $\begin{array}{c}0.414^{* *} \\
(2.19)\end{array}$ & $\begin{array}{l}-0.182 \\
(-0.85)\end{array}$ & $\begin{array}{c}0.172^{* *} \\
(2.48)\end{array}$ & $\begin{array}{l}-0.361 \\
(-1.33)\end{array}$ & $\begin{array}{l}0.243^{*} \\
(1.90)\end{array}$ & $\begin{array}{l}-0.112 \\
(-0.56)\end{array}$ \\
\hline oROE_lag(1) & $\begin{array}{l}-0.0582 \\
(-0.32)\end{array}$ & $\begin{array}{c}0.0876 \\
(0.42)\end{array}$ & $\begin{array}{c}0.00172 \\
(0.03)\end{array}$ & $\begin{array}{c}0.0543 \\
(0.25)\end{array}$ & $\begin{array}{c}-0.0599 \\
(-0.49)\end{array}$ & $\begin{array}{c}0.0936 \\
(0.44)\end{array}$ \\
\hline Growth_TA_lag(1) & $\begin{array}{l}1.490 \\
(1.29)\end{array}$ & $\begin{array}{l}-0.265 \\
(-0.22)\end{array}$ & $\begin{array}{l}0.412 \\
(0.98)\end{array}$ & $\begin{array}{l}-0.338 \\
(-0.27)\end{array}$ & $\begin{array}{l}1.078 \\
(1.39)\end{array}$ & $\begin{array}{l}-0.219 \\
(-0.19)\end{array}$ \\
\hline oDeposit_TA_lag(1) & $\begin{array}{l}0.178 \\
(0.94)\end{array}$ & $\begin{array}{l}-0.343 \\
(-1.58)\end{array}$ & $\begin{array}{c}0.0355 \\
(0.51)\end{array}$ & $\begin{array}{l}-0.356 \\
(-1.53)\end{array}$ & $\begin{array}{l}0.142 \\
(1.12)\end{array}$ & $\begin{array}{l}-0.317 \\
(-1.51)\end{array}$ \\
\hline oOpacity_lag(1) & $\begin{array}{c}-0.380^{* * *} \\
(-2.08)\end{array}$ & $\begin{array}{c}0.0255 \\
(0.12)\end{array}$ & $\begin{array}{c}-0.209^{* * *} \\
(-3.13)\end{array}$ & $\begin{array}{l}0.287 \\
(1.05)\end{array}$ & $\begin{array}{l}-0.171 \\
(-1.39)\end{array}$ & $\begin{array}{c}-0.0628 \\
(-0.33)\end{array}$ \\
\hline Z-Score_lag(1) & $\begin{array}{l}0.155 \\
(1.27)\end{array}$ & $\begin{array}{l}0.127 \\
(1.11)\end{array}$ & $\begin{array}{c}0.0652 \\
(1.46)\end{array}$ & $\begin{array}{c}0.0653 \\
(0.52)\end{array}$ & $\begin{array}{c}0.0900 \\
(1.09)\end{array}$ & $\begin{array}{l}0.142 \\
(1.25)\end{array}$ \\
\hline D_Controlling & $\begin{array}{l}0.456 \\
(1.31)\end{array}$ & $\begin{array}{l}-0.380 \\
(-1.02)\end{array}$ & $\begin{array}{c}0.0808 \\
(0.63)\end{array}$ & $\begin{array}{l}-0.334 \\
(-0.86)\end{array}$ & $\begin{array}{l}0.375 \\
(1.59)\end{array}$ & $\begin{array}{l}-0.389 \\
(-1.06)\end{array}$ \\
\hline RADI & $\begin{array}{c}0.652^{* * *} \\
(2.98)\end{array}$ & $\begin{array}{c}-0.490^{* *} \\
(-2.45)\end{array}$ & $\begin{array}{c}0.0996 \\
(1.25)\end{array}$ & $\begin{array}{l}-0.356^{*} \\
(-1.83)\end{array}$ & $\begin{array}{c}0.552^{* * *} \\
(3.74)\end{array}$ & $\begin{array}{c}-0.532^{* * *} \\
(-2.56)\end{array}$ \\
\hline Individualism & $\begin{array}{c}0.00846 \\
(0.56)\end{array}$ & $\begin{array}{c}0.0153 \\
(1.00)\end{array}$ & $\begin{array}{c}0.0132^{* *} \\
(2.39)\end{array}$ & $\begin{array}{c}-0.0134 \\
(-0.60)\end{array}$ & $\begin{array}{c}-0.00472 \\
(-0.46)\end{array}$ & $\begin{array}{c}0.0258^{*} \\
(1.79)\end{array}$ \\
\hline Observations & 103 & 103 & 103 & 103 & 103 & 103 \\
\hline \multicolumn{7}{|c|}{ Weak instrument robust tests and confidence sets for ivprobit } \\
\hline $\begin{array}{l}\text { Anderson-Rubin test } \\
\quad \text { (p-value) } \\
\text { Wald test } \\
\text { (p-value) }\end{array}$ & & $\begin{array}{c}5.74 \\
(0.0166) \\
6.64 \\
(0.0100) \\
\end{array}$ & & $\begin{array}{c}5.99 \\
(0.0144) \\
6.10 \\
(0.0135) \\
\end{array}$ & & $\begin{array}{c}5.65 \\
(0.0174) \\
6.47 \\
(0.0110) \\
\end{array}$ \\
\hline
\end{tabular}


Table E2: Ownership structure and effectiveness of national supportive measures

This table reports regression estimates of the 2nd stage of the ivprobit models where the dependent variable is $D \_E S O P$. Colum 1, 2, 3 report the results when the Country index, the Legal index and the Fiscal index is instrumented with the number of labor-support-parties, respectively.

\begin{tabular}{|c|c|c|c|}
\hline Dependent variable: & $\begin{array}{c}\text { D_ESOP } \\
(1) \\
\text { ivprobit } \\
\text { 2nd Stage }\end{array}$ & $\begin{array}{c}D \_E S O P \\
(2) \\
\text { ivprobit } \\
\text { 2nd Stage }\end{array}$ & $\begin{array}{c}\text { D_ESOP } \\
\text { (3) } \\
\text { ivprobit } \\
\text { 2nd Stage }\end{array}$ \\
\hline $\begin{array}{l}\text { Instrumented Country index (b1) } \\
\text { Instrumented Country index * D_Controlling (b2) }\end{array}$ & $\begin{array}{l}0.463 * * * \\
(4.68) \\
-0.242 \\
(-1.08)\end{array}$ & & \\
\hline $\begin{array}{l}\text { Instrumented Legal index (b1) } \\
\text { Instrumented Legal index * D_Controlling (b2) }\end{array}$ & & $\begin{array}{l}1.274 * * * \\
(4.30) \\
-0.352 \\
(-0.52)\end{array}$ & \\
\hline $\begin{array}{l}\text { Instrumented Fiscal index (b1) } \\
\text { Instrumented Fiscal index * D_Controlling (b2) }\end{array}$ & & & $\begin{array}{l}0.652 * * * \\
(4.63) \\
-0.401 \\
(-1.28)\end{array}$ \\
\hline D_Controlling & $\begin{array}{l}0.540 \\
(0.61)\end{array}$ & $\begin{array}{l}0.353 \\
(0.28)\end{array}$ & $\begin{array}{l}0.377 \\
(0.57)\end{array}$ \\
\hline Size_lag(1) & $\begin{array}{c}0.185^{* * *} \\
(2.67)\end{array}$ & $\begin{array}{c}0.180^{* * * *} \\
(2.69)\end{array}$ & $\begin{array}{c}0.189^{* * * *} \\
(2.74)\end{array}$ \\
\hline oEquity_TA_lag(1) & $\begin{array}{c}-0.0412 \\
(-0.23)\end{array}$ & $\begin{array}{c}-0.0969 \\
(-0.50)\end{array}$ & $\begin{array}{c}-0.00553 \\
(-0.03)\end{array}$ \\
\hline oROE_lag(1) & $\begin{array}{c}0.0815 \\
(0.39)\end{array}$ & $\begin{array}{c}0.0705 \\
(0.36)\end{array}$ & $\begin{array}{c}0.0840 \\
(0.40)\end{array}$ \\
\hline Growth_TA_lag(1) & $\begin{array}{l}0.185 \\
(0.15)\end{array}$ & $\begin{array}{l}0.163 \\
(0.15)\end{array}$ & $\begin{array}{l}0.240 \\
(0.20)\end{array}$ \\
\hline oDeposit_TA_lag(1) & $\begin{array}{l}-0.251 \\
(-1.22)\end{array}$ & $\begin{array}{l}-0.267 \\
(-1.23)\end{array}$ & $\begin{array}{l}-0.225 \\
(-1.15)\end{array}$ \\
\hline oOpacity_lag(1) & $\begin{array}{l}-0.111 \\
(-0.56)\end{array}$ & $\begin{array}{c}0.0104 \\
(0.05)\end{array}$ & $\begin{array}{l}-0.161 \\
(-0.85)\end{array}$ \\
\hline Z-Score_lag(1) & $\begin{array}{l}0.147 \\
(1.29)\end{array}$ & $\begin{array}{l}0.108 \\
(0.96)\end{array}$ & $\begin{array}{l}0.155 \\
(1.37)\end{array}$ \\
\hline RADI & $\begin{array}{c}-0.394^{* *} \\
(-2.11)\end{array}$ & $\begin{array}{c}-0.346^{* *} \\
(-1.97)\end{array}$ & $\begin{array}{c}-0.409^{* *} \\
(-2.15)\end{array}$ \\
\hline Individualism & $\begin{array}{c}0.0255^{*} \\
(1.69)\end{array}$ & $\begin{array}{l}0.0105 \\
(0.64)\end{array}$ & $\begin{array}{c}0.0327^{* * *} \\
(2.20)\end{array}$ \\
\hline Observation & 103 & 103 & 103 \\
\hline \multicolumn{4}{|l|}{ Wald test } \\
\hline $\mathrm{b} 1+\mathrm{b} 2=0$ & $\begin{array}{c}0.221 \\
(0.952)\end{array}$ & $\begin{array}{c}0.922 \\
(1.630)\end{array}$ & $\begin{array}{c}0.251 \\
(0.661)\end{array}$ \\
\hline
\end{tabular}

The t-statistics are in parentheses, with *,**, and $* * *$ denoting significance at $10 \%, 5 \%$ and $1 \%$ levels. 
Table E3: Ownership structure, degrees of opacity, and effectiveness of national supportive measures

This table reports regression estimates of the 2nd stage of the ivprobit models where the dependent variable is D_ESOP. Colum 1, 2, 3 report the results when Country index, Legal index and Fiscal index is instrumented with the number of labor-support-parties, respectively.

\begin{tabular}{|c|c|c|c|}
\hline Dependent variable: & $\begin{array}{c}D \_E S O P \\
(1) \\
\text { ivprobit } \\
\text { 2nd Stage }\end{array}$ & $\begin{array}{c}D \_E S O P \\
(2) \\
\text { ivprobit } \\
\text { 2nd Stage }\end{array}$ & $\begin{array}{c}\text { D_ESOP } \\
\text { (3) } \\
\text { ivprobit } \\
\text { 2nd Stage }\end{array}$ \\
\hline IV_Country index (b1) & $\begin{array}{l}1.791 * * * \\
(3.27)\end{array}$ & & \\
\hline IV_Country index * D_Controlling (b2) & $\begin{array}{c}-1.237^{* * *} \\
(-2.71)\end{array}$ & & \\
\hline IV_Country index *D_Opacity (b3) & $\begin{array}{l}-0.928^{* *} \\
(-1.99)\end{array}$ & & \\
\hline IV_Country index * D_Controlling * D_Opacity (b4) & $\begin{array}{l}0.622^{* *} \\
(2.36)\end{array}$ & & \\
\hline IV_Legal index (b1) & & $\begin{array}{l}4.081 * * * \\
(2.75)\end{array}$ & \\
\hline IV_Legal index * D_Controlling (b2) & & $\begin{array}{l}-2.208^{*} \\
(-1.79)\end{array}$ & \\
\hline IV_Legal index *D_Opacity (b3) & & $\begin{array}{l}-1.463 \\
(-1.31)\end{array}$ & \\
\hline IV_Legal index * D_Controlling * D_Opacity (b4) & & $1.003^{* *}$ & \\
\hline IV_Fiscal index (b1) & & & $\begin{array}{l}2.970 * * * \\
(2.94)\end{array}$ \\
\hline IV_Fiscal index * D_Controlling (b2) & & & $\begin{array}{c}-2.266^{* * *} \\
(-2.59)\end{array}$ \\
\hline IV_Fiscal index * D_Opacity (b3) & & & $\begin{array}{c}-1.821^{* *} \\
(-1.96)\end{array}$ \\
\hline IV_Fiscal index * D_Controlling * D_Opacity (b4) & & & $1.431^{* *}$ \\
\hline D_Opacity & $\begin{array}{l}2.106 \\
(1.64)\end{array}$ & $\begin{array}{l}2.142 \\
(1.19)\end{array}$ & $\begin{array}{l}1.535 \\
(1.57)\end{array}$ \\
\hline D_Controlling & $\begin{array}{l}2.535^{* *} \\
(2.09)\end{array}$ & $\begin{array}{l}2.638 \\
(1.32) \\
\end{array}$ & $\begin{array}{l}1.801^{* *} \\
(2.12)\end{array}$ \\
\hline Control variables & Yes & Yes & Yes \\
\hline Observation & 103 & 103 & 103 \\
\hline \multicolumn{4}{|l|}{ Wald tests } \\
\hline $\mathrm{b} 1+\mathrm{b} 2=0$ & $\begin{array}{c}0.553 * * \\
(4.288)\end{array}$ & $\begin{array}{l}1.873 * * \\
(5.791)\end{array}$ & $\begin{array}{l}0.704^{*} \\
(3.216)\end{array}$ \\
\hline $\mathrm{b} 1+\mathrm{b} 3=0$ & $\begin{array}{c}0.862 * * * \\
(6.731)\end{array}$ & $\begin{array}{l}2.617 * * \\
(4.882)\end{array}$ & $\begin{array}{c}1.148 * * * \\
(6.884)\end{array}$ \\
\hline$b 1+b 2+b 3+b 4=0$ & $\begin{array}{c}0.247 \\
(0.663)\end{array}$ & $\begin{array}{l}1.412 \\
(2.045)\end{array}$ & $\begin{array}{c}0.313 \\
(0.537)\end{array}$ \\
\hline
\end{tabular}

The t-statistics are in parentheses, with *,**, and *** denoting significance at $10 \%, 5 \%$ and $1 \%$ levels. 
Table E4: Ownership structure, levels of of shareholder protection, and effectiveness of national supportive measures

This table reports regression estimates of the 2nd stage of the ivprobit models where the dependent variable is D_ESOP. Colum 1, 2, 3 report the results when Country index, Legal index and Fiscal index is instrumented with the number of labor-support-parties, respectively.

\begin{tabular}{|c|c|c|c|}
\hline Dependent variable: & $\begin{array}{c}D \_E S O P \\
(1) \\
\text { ivprobit } \\
\text { 2nd Stage }\end{array}$ & $\begin{array}{c}D \_E S O P \\
(2) \\
\text { ivprobit } \\
\text { 2nd Stage }\end{array}$ & $\begin{array}{c}D \_E S O P \\
(3) \\
\text { ivprobit } \\
\text { 2nd Stage }\end{array}$ \\
\hline IV_Country index (b1) & $\begin{array}{c}1.591^{* * *} \\
(3.61)\end{array}$ & & \\
\hline IV_Country index $*$ D_Controlling (b2) & $\begin{array}{c}-0.614^{* * *} \\
(-1.96)\end{array}$ & & \\
\hline IV_Country index * D_RADI (b3) & $\begin{array}{l}-0.570 \\
(-1.13)\end{array}$ & & \\
\hline IV_Country index * D_Controlling * D_RADI (b4) & $\begin{array}{l}-0.238 \\
(-0.96)\end{array}$ & & \\
\hline IV_Legal index (b1) & & $\begin{array}{c}4.814^{* * * *} \\
(2.96)\end{array}$ & \\
\hline IV_Legal index * D_Controlling (b2) & & $\begin{array}{l}-1.383 \\
(-1.36)\end{array}$ & \\
\hline IV_Legal index * D_RADI (b3) & & $\begin{array}{l}-1.441 \\
(-1.05)\end{array}$ & \\
\hline IV_Legal index * D_Controlling * D_RADI (b4) & & $\begin{array}{l}-0.313 \\
(-0.69)\end{array}$ & \\
\hline IV_Fiscal index (b1) & & & $\begin{array}{c}2.055^{* * *} \\
(3.74)\end{array}$ \\
\hline IV_Fiscal index * D_Controlling (b2) & & & $\begin{array}{l}-0.795^{*} \\
(-1.96)\end{array}$ \\
\hline IV_Fiscal index * D_RADI (b3) & & & $\begin{array}{l}-0.632 \\
(-0.91)\end{array}$ \\
\hline IV_Fiscal index * D_Controlling * D_RADI (b4) & & & $\begin{array}{l}-0.543 \\
(-1.16)\end{array}$ \\
\hline D_RADI & $\begin{array}{c}4.229 * * \\
(2.48)\end{array}$ & $\begin{array}{l}4.100^{*} \\
(1.76)\end{array}$ & $\begin{array}{c}3.498 * * * \\
(2.92)\end{array}$ \\
\hline D_Controlling & $\begin{array}{l}1.881 \\
(1.60) \\
\end{array}$ & $\begin{array}{l}2.216 \\
(1.25) \\
\end{array}$ & $\begin{array}{r}1.107 \\
(1.41) \\
\end{array}$ \\
\hline Control variables & Yes & Yes & Yes \\
\hline Observation & 103 & 103 & 103 \\
\hline \multicolumn{4}{|l|}{ Wald tests } \\
\hline $\mathrm{b} 1+\mathrm{b} 2=0$ & $\begin{array}{l}0.977 * * \\
(5.993)\end{array}$ & $\begin{array}{c}3.431 * * \\
(5.943)\end{array}$ & $\begin{array}{c}1.259 * * \\
(6.107)\end{array}$ \\
\hline $\mathrm{b} 1+\mathrm{b} 3=0$ & $\begin{array}{l}1.022^{* *} \\
(5.761)\end{array}$ & $\begin{array}{c}3.372 * * * \\
(7.395)\end{array}$ & $\begin{array}{l}1.423^{* *} \\
(5.395)\end{array}$ \\
\hline$b 1+b 2+b 3+b 4=0$ & $\begin{array}{c}0.169 \\
(0.499)\end{array}$ & $\begin{array}{c}1.676 \\
(0.049)\end{array}$ & $\begin{array}{c}0.084 \\
(0.064)\end{array}$ \\
\hline
\end{tabular}

The t-statistics are in parentheses, with *,**, and $* * *$ denoting significance at $10 \%, 5 \%$ and $1 \%$ levels. 